The Catholic University of America, Columbus School of Law

CUA Law Scholarship Repository

1978

\title{
Attorney's Affidavit in Litigation Proceedings
}

John H. Garvey

The Catholic University of America, Columbus School of Law

Follow this and additional works at: https://scholarship.law.edu/scholar

Part of the Civil Procedure Commons, and the Litigation Commons

\section{Recommended Citation}

John H. Garvey, Attorney's Affidavit in Litigation Proceedings, 31 STAN. L. REV. 191 (1978).

This Article is brought to you for free and open access by the Faculty Scholarship at CUA Law Scholarship Repository. It has been accepted for inclusion in Scholarly Articles and Other Contributions by an authorized administrator of CUA Law Scholarship Repository. For more information, please contact edinger@law.edu. 


\title{
The Attorney's Affidavit in Litigation Proceedings
}

\author{
John H. Garvey*
}

\section{AN InTRODUCtion to AtTORnEy AFFIDAVITS}

Although until the early 1800's Anglo-American law perceived no impropriety in an attorney testifying for his client, ${ }^{1}$ the accepted learning in this country for more than a century has been that counsel may legitimately act as both advocate and witness in the same case only in unusual circumstances. ${ }^{2}$ Yet despite the general prohibition on live testimony by counsel, attorneys commonly file their own affidavits in their clients' behalf at various stages of the litigation proceedings. The question of attorney affidavits surfaces very rarely in reported judicial opinions, ${ }^{3}$ since the practice occurs most frequently in connection with motions seeking or opposing some form of interlocutory relief. More curious is the complete absence of scholarly discussion of such activity, which presents complex questions of professional responsibility and attorney work product. This article addresses those issues and suggests criteria by which both courts and counsel may evaluate the professional propriety and legal consequences of attorney affidavits.

As might be'expected, an attorney's choice to proceed on his own, rather than another's, affidavit is one which occurs with less frequency as the distance from trial decreases. Statements by counsel are best accepted and most permissible for purely formal and noncontroversial purposes related to the initiation of lawsuits, such as

* A.B. 1970, University of Notre Dame; J.D. 1974, Harvard University. Assistant Pro- fessor of Law, Kentucky College of Law.

1. $6 \mathrm{~J}$. WIGMORE, EVIDENCE $§ 1911$, at 774 (Chadbourne rev. 1976).

2. E.g., ABA CODE OF PROFESSIONAL REsPONSIBILITY, DR 5-102: "If, after undertaking employment in contemplated or pending litigation, a lawyer learns or it is obvious that he or a lawyer in his firm ought to be called as a witness on behalf of his client, he shall withdraw from the conduct of the trial and his firm, if any, shall not continue representation in the trial ...." See id. EC 5-9 \& 5-10, DR 5-101. See generally 6 J. WIGMORE, supra note 1, § 1911.

3. See note 7 infra. 
attesting to the lawyer's role as legal guardian, executor, or administrator, ${ }^{4}$ or verification of pleadings in behalf of a client. Though most jurisdictions prefer verification by a party, counsel's verification is widely authorized by statute ${ }^{5}$ and contemplated by the Code of Professional Responsibility. ${ }^{6}$

The discovery process also lends itself to frequent intervention by counsel in the role of participant. Some affidavits, however, relate merely to "formal" matters, which cannot await presentation at trial or be addressed by normal witnesses, and will seldom raise ethical and work product issues. An attorney may file an affidavit concerning his own conduct in discovery matters, or the conduct of the parties or opposing counsel. ${ }^{7}$ For example, when a party seeks discovery of documents which may be in the possession of counsel for the re-

4. See ABA Ganons of Professional Ethics No. 11.

5. Although verification has lost most of its significance in the wake of procedural reform, it continues to be permitted-and occasionally even required-under the Federal Rules of Civil Procedure and many state statutory schemes. See, e.g., FED. R. Crv. P. 11; ALA. R. Crv. P. 11; Gal. Grv. Proc. Code $\S 446$ (West Supp. 1978); Colo. R. Crv. P. 11; Fla. R. Grv. P. 1.03g; Ill. AnN. STAT. ch. 110, $\$ 35$ (Smith-Hurd 1968); LA. Code Crv. Pro. ANN. art. 863 (West 1961); Mass. R. Civ. P. 11; MiCh. General Cr. R. 114; MinN. R. CIv. P. 11; N.J. R. Cr. 1:4-7; N.Y. Giv. Prac. § 3020(d); N.D. R. Giv. P. 11; OHIo R. Giv. P. 11; OR. Rev. Stat. § 16.070 (1977); PA. R. Giv. P. 1024; Wash. Super. GT. GIv. R. 11; Wis. Stat. ANN. $\S 802.05$ (West 1977); WYO. R. Crv. P. 11. The general preference for verification by the party is most easily overcome when the party resides outside the county where the attorney has his office, CaL. Crv. Proc. CODE $§ 446$ (West Supp. 1978); MD. R. Proc. 303, § b(3) (party absent from state); MONT. REv. CODEs ANN. § 93-3702 (1964); NEv. REv. STAT. $\S 15.010$ (1977); N.Y. Grv. Prac. § 3020(d); OR. Rev. STat. § 16.070 (1977); Pa. R. Grv. P. 1024 (c) (party outside jurisdiction and verification cannot be obtained in time for filing); S.C. CODE $\S 15-13-40$ (1977), or is for some cause not able to execute the verification, CAL. Crv. Proc. Code $\S 446$ (West Supp. 1978); MD. R. Proc. 303, § b(3); Mont. Rev. Codes AnN. § 93-3702 (1964); Nev. Rev. STAT. § 15.010 (1977); OR. Rev. STAT. § 16.070 (1977); S.C. CODE $\S 15-13-40$ (1977). Counsel may also be permitted to verify where the action or defense is based on a written instrument for the payment of money, which is in counsel's possession, N.Y. Crv. Prac. $\S 3020$ (d); N.C. R. Crv. P. § 1A-1, Rule 11(c); OR. Rev. Stat. $\S 16.070$ (1977); S.C. CODE § 15-13-40 (1977); see TENN. CODE ANN. § 20-703 (1955), or where the lawyer has personal knowledge of the facts on which the pleading is based, CAL. Civ. Proc. Code $\S 446$ (West Supp. 1978); Ill. ANN. STAT. ch. 110, § 35 (Smith-Hurd 1968); Mich. General CT. R. 114.3; Nev. Rev. Stat. $\$ 15.010$ (1977); N.Y. Civ. Prac. $\S 3020$ (d); N.C. R. Civ. P. § 1A-1, Rule 11(c); OR. REv. STAT. § 16.070 (1977); S.C. CODE $\S 15-13-40$ (1977), and in some cases, with no restrictions at all, ARIZ. R. Crv. P. 11(b) (any person "acquainted with the facts"); ARK. STAT. ANN. § 27-1107 (1962); IND. CoDE § 34-5-1-1, Trial Rule 11(c) (1976) ("reasonable cause to believe" matters therein); WYo. R. Civ. P. 11(b).

6. See ABA Code of Professional Responsibility, EC 7-25 ("[A] lawyer should subscribe to or verify only those pleadings that he believes are in compliance with applicable law and rules .....".

7. Such an affidavit parallels an attorney's description under oath of the unsuccessful steps he has taken to obtain information which opposing counsel holds, as part of a showing of hardship under FED. R. CrV. P. 26(b)(3) in a motion for production. Or counsel may support a motion for a protective order under FED. R. Crv. P. 26(c) by stating under oath 
sponding party, it may be not only proper but even necessary for the responding attorney to state by way of affidavit that the materials are no longer in existence, or have been mislaid, since he may be the only person with first-hand knowledge of those facts. ${ }^{8}$ As the agent of the responding party he may have a duty to produce the documents, absent any work product protection. ${ }^{9}$ Furthermore, when a party seeks sanctions for the opposition's failure to make discovery, the court is likely to be interested in learning what the opposing attorney's actions have been, since the nature of an appropriate order will often turn on the willfulness of the party's refusal to cooperate. ${ }^{10}$

But serious ethical and work product questions do arise when counsel files an affidavit regarding the merits of the litigation or the

that he cannot attend a deposition at a certain time because of an unforeseen emergency and asking that the session be postponed.

Affidavits filed by counsel going to such matters as the propriety of service of process also present no problems of the kind dealt with here. See, e.g., Bucholz v. Hutton, 153 F. Supp. 62 (D. Mont. 1957); cf. Agrio v. Oceanic Operations Corp., 204 F. Supp. 10 (S.D.N.Y. 1961) (affidavit of counsel for plaintiff arguing existence of subject matter jurisdiction in Jones Act case); De Sairigne v. Gould, 83 F. Supp. 270 (S.D.N.Y. 1949) (forum non conveniens, where defendant resided in France and was unable to travel to the United States). Although it may sometimes happen that the question of jurisdiction or service of process is inextricably bound up with the merits of the controversy, see Grace v. MacArthur, 170 F. Supp. 442 (E.D. Ark. 1959), most typically statements by counsel regarding such matters will have no spillover effects beyond the determination of a narrow preliminary question. And in questions of personal jurisdiction it may happen that counsel is the only one around.

8. See, e.g., Jensen v. Boston Ins. Co., 20 F.R.D. 619 (N.D. Cal. 1957). In Jensen, a motion for production under Rule 34 was "supported by an affidavit of defendant's counsel in which it is sworn on information and belief that the documents are in the possession or under the custody of the third party defendants; that the documents must be produced in order for defendant to conduct its cross-examination of its opponents; and that the documents are 'material and necessary to the completion of the investigation of the defense of the action on such complaint and to proving the action under said third party complaint.' Defendant's counsel further swears that [the third party defendant] refused to produce the documents after being requested to do so by the affiant . . .." Id. at 621 . The third party defendant claimed orally that the documents were no longer in existence, to which claim the court replied that "if the documents sought are not in existence, it is incumbent upon the objecting party or parties to so state under oath and not by way of a general unverified allegation." Id.

For a recent example of the gravity of the duty imposed on counsel in such circumstances, note the stir created by Kodak's defense of an antitrust suit by Berkey Photo Inc. when Mahlon Perkins, an attorney who had handled part of Kodak's discovery, filed an affidavit stating that he had discarded certain documents which in fact had been retained. Wall St. J., Mar. 30, 1978, at 8, col. 1.

9. "Any party may serve on any other party a request (1) to produce . . . documents ... which are in the possession, custody or control of the party upon whom the request is served . . . ." FED. R. Crv. P. 34(a); see In re Ruppert, 309 F.2d 97 (6th Cir. 1962); 8 C. Wright \& A. Miller, Federal Practice and Procedure $§ 2210$ (1970).

10. See National Hockey League v. Metropolitan Hockey Club, Inc., 427 U.S. 639 (1976) (per curiam); Note, The Emerging Deterrence Orientation in the Imposition of Discovery Sanctions, 91 HaRv. L. REv. 1033 (1978). 
facts and issues in controversy, and thereby becomes a quasi-witness, offering information with respect to substance rather than process. This information generally could be put forward by other means, as it would be at trial, and thus an attorney bears a heavy burden in justifying such an affidavit. For example, suppose that in the course of discovery counsel wishes to expedite the schedule for depositions, responses to interrogatories, production of documents, or requests for admissions. ${ }^{11}$ The attorney may state by way of affidavit, and on information and belief, that his client will suffer irreparable harm from the defendant's actions if the proceedings are not concluded with all possible haste, and include in the affidavit his sources of information and grounds for belief. ${ }^{12}$ To be sure, the order being sought is technically procedural, and does not in any way determine the ultimate outcome of the case. But by offering under oath his views on the substance of the controversy the attorney has become a participant in the litigation in a way not normally contemplated for attorneys, having given fact or belief which might well have been provided from another source. Clearly, if the court gives weight to the attorney's statements and orders expedition, the opposing party may suffer from being given less time to hire a lawyer and prepare to respond. The issue thus offers more than academic interest.

Counsel may also offer his own affidavit in connection with applications for preliminary injunctions or temporary restraining orders, ${ }^{13}$ proceedings in which the strict evidentiary standards associated with motions for summary judgment ${ }^{14}$ apparently give way to the need for

11. See Fed. R. Grv. P. 30(a) ("Leave of court . . . must be obtained . . . if the plaintiff seeks to take a deposition prior to the expiration of 30 days after service of the summons and complaint upon any defendant . . .."); FED. R. Crv. P. 33(a) ("The court may allow a shorter . . . time [for filing responses to interrogatories]."); FED. R. Civ. P. 34(b) ("The court may allow a shorter . . . time [for response to a request for production of documents]."); FED. R. Grv. P. 36(a) ("[U]nless the court shortens the time, a defendant shall not be required to serve answers or objections [to a request for admission] before the expiration of 45 days after service of the summons and complaint on him.").

12. Suppose, to be a little more concrete, that company $A$, seeking by means of a lawsuit to avoid a takeover by company $B$, desires expedited discovery so that the merits may be resolved before a tender offer is made. Given the extreme time pressures which characterize tender offers, $A$ 's attorney may well file his own affidavit in support of such a motion, and in it state on information and belief the deleterious consequences which would result to $A$ from the takeover. The harm alleged could be the very basis for $A$ 's claim for equitable relief on the merits as well.

13. Fed. R. Grv. P. 65(b).

14. The rule on summary judgment, FED. R. Civ. P. 56(e), provides that "[s]upporting and opposing affidavits shall be made on personal knowledge, shall set forth such facts as would be admissible in evidence, and shall show affirmatively that the affiant is competent to testify to the matters stated therein." 
speedy relief. ${ }^{15}$ When there is no real dispute as to material facts, ${ }^{16}$ or when other circumstances appeal to the discretion of the trial judge, ${ }^{17}$ a temporary injunction may issue on the basis of affidavits, one or more of which may come from an attorney. ${ }^{18}$ Such an affida-

15. Unlike Rule 56, see note 14 supra, the rule on injunctions, FED. R. CIV. P. 65, does not require that an affidavit "set forth such facts as would be admissible in evidence." First, because it does not ordinarily dispose of the case on the merits, interlocutory injunctive relief has a less drastic impact than summary judgment. Moreover, the party enjoined may protect itself either by posting security, or, where necessary, obtaining dissolution of the order before trial. Perhaps most important, on motions for injunctive relief the parties may find it impossible to marshal adequate admissible evidence within the time framework contemplated by the rules. 7 MOORE's Federal Practice If 65.04[3], at 65-64 (2d ed. 1978); see Wounded Knee Legal Defense/Offense Comm. v. FBI, 507 F.2d 1281, 1286-87 (8th Cir. 1974); SEC v. General Refractories Co., 400 F. Supp. 1248, 1255 (D.D.C. 1975). "Finally, inasmuch as the grant of a preliminary injunction is discretionary, the trial court should be allowed to give even inadmissible evidence some weight when it is thought advisable to do so in order to serve the primary purpose of preventing irreparable harm before a trial can be had." $11 \mathrm{C}$. WRIGHT \& A. MILLER, supra note $9, \S 2949$, at 471 .

16. Compare K-2 Ski Co. v. Head Ski Co., 467 F.2d 1087 (9th Cir. 1972), with Safeway Stores, Inc. v. Safeway Properties, Inc., 307 F.2d 495 (2d Cir. 1962). In Safeway, the court observed that "the granting of a preliminary injunction is within the sound discretion of the trial court . . . . It appears to us that there is little genuine controversy as to the basic facts .... Accordingly, the rights of the parties were well enough established by the affidavits and pleadings for the trial court in its discretion to issue the preliminary injunction." Id. at 500 . In $K-2$ Ski Co., after noting that a preliminary injunction might properly be based on affidavits, the court warned that "if the facts so appearing consist largely of general assertions which are substantially controverted by counter-affidavits, a court should not grant such relief unless the moving party makes a further showing sufficient to demonstrate that he will probably succeed on the merits." 467 F.2d at 1088-89.

17. See SEC v. Koenig, 469 F.2d 198, 202 (2d Cir. 1972) (continued violations of securities laws and failure to correct errors in SEC filings and press releases); San Francisco-Oakland Newspaper Guild v. Kennedy, 412 F.2d 541, 546 (9th Cir. 1969) (reasonable cause to believe unfair labor practices being committed); Ross-Whitney Corp. v. Smith, Kline \& French Laboratories, 207 F.2d 190, 198 (2d Cir. 1953) (danger of "irreparable injury" if no speedy relief, though bond posted to protect enjoined party); SEC v. General Refractories Co., 400 F. Supp. 1248 (D.D.C. 1975) (showing of need sufficient for injunction against SEC violation if evidence not in dispute).

18. Many of the attorneys filing affidavits in connection with preliminary injunction requests are associated with government regulatory agencies, a fact which obscures the study of attorney affidavit practice in two ways.

First, an attorney for an agency such as the SEC may possess detailed knowledge of the facts and issues stated in his affidavit, because of his knowledge of the field, his work in investigating the matter, and his access to a vast body of specialized information within the agency. The fact that he is also an attorney may be quite incidental to the affidavit's role in the injunction proceeding.

Second, government attorneys may be favored by statutes which, in the language of many preliminary injunction opinions, effectively "tip the scales" in favor of preliminary injunctions. See, e.g., FTC v. Sterling Drugs, Inc., 317 F.2d 669, 678 (2d Cir. 1963); FTC v. Rhodes Pharmacal Co., 191 F.2d 744, 747 (7th Cir. 1951) (congressional intent to relax nor$\mathrm{mal}$ equitable standards for the granting of injunctive relief found in language of $\S 13(\mathrm{a})$ of the Federal Trade Commission Act, 15 U.S.C. § 53(9) (1976)). Thus, when a court grants a 
vit adds a substantial dimension to counsel's participation in litigation and may cause severe detriment to the opposing party. ${ }^{19}$

Opinions dealing with motions for summary judgment,${ }^{20}$ perhaps simply because they are most often reported, indicate most clearly the frequency with which counsel attempts to take an active role in the litigation through the filing of an affidavit. The requirements for affidavits in support of a motion for summary judgment are strict, ${ }^{21}$ and so counsel's affidavit may only in limited instances affect the outcome of the motion. ${ }^{22}$ But these requirements do not seem to deter attorneys from filing such affidavits when they feel they have acquired knowledge in the course of preparing for a case which renders them especially competent to testify to particular facts. For example, counsel who has studied the operation of a machine in an action for patent infringement may offer his statement in order to defend on the basis of anticipation by prior art. ${ }^{23}$ In other cases, the attorney

preliminary injunction on the basis of affidavits filed by government attorneys, it is difficult to tell whether the court would have accorded similar respect to a private attorney's affidavit. Yet some private counsel have the same depth of knowledge with respect to their clients that a government agency attorney might have in his particular field, especially a private corporate counsel with a long-standing relationship to the corporation.

19. The more severe the detriment, however, the more likely it is that the court will resort to additional methods of factfinding-including an evidentiary hearing - before granting injunctive relief. See SEC v. Frank, 388 F.2d 486, 490-93 (2d Cir. 1968); Sims v. Greene, 161 F.2d 87 (3d Cir. 1947). FED. R. CrV. P. 65(a)(2) provides that "the court may order the trial of the action on the merits to be advanced and consolidated with the hearing of the application [for preliminary injunction]." With such a wide range of discretion available, a court's use of attorney affidavits in granting or denying an injunction order would depend heavily on the particular circumstances of the case.

20. FED. R. Crv. P. 56.

21. "Supporting and opposing affidavits shall be made on personal knowledge, shall set forth such facts as would be admissible in evidence, and shall show affirmatively that the affiant is competent to testify to the matters stated therein." FED. R. CrV. P. 56(e).

22. Courts frequently refuse to consider attorney affidavits on the ground that counsel has ignored the personal knowledge requirement of FED. R. Grv. P. 56(e). E.g., Automatic Radio Mfg. Co. v. Hazeltine Research, Inc., 339 U.S. 827 (1950); Bumgarner v. Joe Brown Co., 376 F.2d 749 (10th Cir.), cert. denied, 389 U.S. 831 (1967); Local 490, United Rubber Workers v. Kirkhill Rubber Co., 367 F.2d 956 (9th Cir. 1966); F.S. Bowen Elec. Co. v. J.D. Hedin Constr. Co., 316 F.2d 362 (D.C. Cir. 1963); Hoston v. J.R. Watkins Co., 300 F.2d 869 (9th Cir. 1962); Mercantile Nat'l Bank v. Franklin Life Ins. Co., 248 F.2d 57 (5th Cir. 1957); Flintkote Co. v. United States, 47 F.R.D. 322 (S.D.N.Y. 1969); Johns Hopkins Univ. v. Hutton, 297 F. Supp. 1165 (D. Md. 1968), affd in part, rev'd in part on other grounds, 422 F.2d 1124 (4th Cir. 1970), cert. denied, 416 U.S. 916 (1974); Christophides v. Porco, 289 F. Supp. 403 (S.D.N.Y. 1968); Noth v. Scheurer, 285 F. Supp. 81 (E.D.N.Y. 1968); Graham v. Pennsylvania R.R., 13 Fed. R. Serv. 943 (S.D. Ohio 1949).

23. See Inglett \& Co. v. Everglades Fertilizer Co., 255 F.2d 342 (5th Cir. 1958). In Ingletl, counsel was sharply criticized for submitting "uncontroverted facts" in the form of what was actually an argumentative affidavit. See J. WiGMORE, supra note 1, § 1911(3), at 780; text accompanying notes $69-73$ infra. 
may have heard an admission by an opposing party, ${ }^{24}$ or may as the result of an investigation be able to demonstrate facts undisputed by the other party. ${ }^{25}$ To the extent that a court looks to such an affidavit for support of a summary judgment motion, counsel becomes an active participant in the determination of the merits. ${ }^{26}$

A final situation in which attorneys frequently file affidavits on behalf of their clients is a motion for a new trial. ${ }^{27}$ The distinction between counsel's statements simply related to his observation of the litigation and those dealing with the substance of the controversy applies here as well. For example, motions for new trial based on grounds appearing in the record-that there was error in admitting evidence, or giving instructions, or that the verdict is against the law or the weight of the evidence, or that the amount of an award is excessive or inadequate-may be supported by an affidavit of counsel which does no more than recite his recollection of events which transpired in the course of trial.

But problems may arise when counsel seeks to substantiate a motion for new trial through facts outside the record-newly discovered evidence ${ }^{28}$ misconduct in the jury's deliberations, ${ }^{29}$ or misconduct of

24. See Douglas v. Beneficial Fin. Co., 334 F. Supp. 1166 (D. Alas. 1971), rev'd in part on other grounds, 469 F.2d 453 (9th Cir. 1972) (affidavit by attorneys present at deposition reporting events at deposition).

25. See, e.g., Lula v. Sivaco Wire \& Nail Co., 265 F. Supp. 222 (S.D.N.Y. 1967). In Lula, defendant's investigators learned that a mother claiming mental anguish had not been present at the scene of an accident to see her child injured, a fact which the plaintiff did not dispute. Defense counsel submitted this information in affidavit form. The court, observing that "ordinarily such affidavits not made on personal knowledge would be insufficient on a motion for summary judgment," was willing nonetheless to rule in the case before it because the situation was "clear." Id. at 224.

26. Once again it is necessary to distinguish situations in which counsel must offer his evidence because he is a direct part of the controversy, as when an attorney in an action asserts a claim for his fee, see, e.g., United States Fidelity \& Guar. Co. v. Moore, 306 F. Supp. 1088 (N.D. Miss. 1969) (affidavits of attorney intervenors recount fee agreement with defendants in claim for money found in defendants' possession), or is indirectly involved, as in a suit for malicious prosecution where the defense of advice of counsel is raised, see, e.g., Stephens v. Brown \& Root, 338 F. Supp. 680 (W.D. La. 1971), affd per curiam, 455 F.2d 1383 (5th Cir. 1972).

27. See FED. R. Grv. P. 59.

28. See, e.g., Edgar v. Finley, 312 F.2d 533 (8th Cir. 1963) (motion for new trial should have been granted where defendant exercised due diligence in trying to get accident witnesses' names and addresses from plaintiff before trial but did not receive information until after trial).

One leading case states that for a movant to prevail on a motion for new trial based on newly discovered evidence, "there must ordinarily be present and concur five verities, to wit: (a) The evidence must be in fact, newly discovered, i.e., discovered since the trial; (b) facts must be alleged from which the court may infer diligence on the part of the movant; (c) the evidence relied on, must not be merely cumulative or impeaching; (d) it must be material to 


\section{the opposing party or counsel outside the courtroom. ${ }^{30}$ When coun-} sel's affidavit meets the required standard of proof, ${ }^{31}$ its contribution to the substance of the case might seriously harm the opposing

the issues involved; and (e) it must be such, and of such nature, as that, on a new trial, the newly discovered evidence would probably produce an acquittal." Johnson v. United States, 32 F.2d 127, 130 (8th Cir. 1929). Courts are notably reluctant to accept affidavits from attorneys in this regard, since the newly discovered evidence ought to be available in affidavit form directly from appropriate witnesses. See, e.g., In re Weltzien, 68 F. Supp. 1000 (S.D.N.Y. 1946); Collins v. Central Trust Co., 135 Misc. 465, 238 N.Y.S. 226 (Sup. Ct. 1929). But where, as in Edgar v. Finley, the issue is the attorney's own diligence and opportunity to obtain the evidence before trial, as in categories (a) and (b) above, his own affidavit may be not only acceptable but crucial. But of. Kleinschmidt v. United States, 146 F. Supp. 253 (D. Mass. 1956) (attorney's affidavit describing plaintiff's diligence insufficient where plaintiff's own affidavit made no mention of efforts).

29. Normally the juror or other individual with first-hand knowledge of the misconduct must be produced; courts hesitate to rely on an attorney's affidavit as to what a juror told him. Thus in United States v. Gegax, 506 F.2d 460 (9th Cir. 1974), the court rejected a motion for new trial supported by defense counsel's affidavit that a juror claimed to have discussed a fact with her husband; affidavits from the juror or the husband were necessary. In State v. James, 70 Wash. 2d 624, 424 P.2d 1005 (1967), according to defense counsel's affidavit, the jurors had conducted experiments in the jury room, thereby creating grounds for setting aside the verdict; but the court insisted that the jurors themselves state first-hand what occurred during deliberations. But see note 31 infra.

30. In Julien v. Barker, 75 Idaho 413, 272 P.2d 718 (1954), a wrongful death action involving medical malpractice, plaintiff's attorneys moved for a new trial, supporting the motion with an attorney affidavit asserting that the defense had intimidated expert medical witnesses into withdrawing their offers of testimony for plaintiff at the last moment. The court was sympathetic to the possibility of such intimidation, but declined to grant a new trial when there was no showing by plaintiff's counsel as to why the doctors' affidavits could not be had, or that the same intimidation would preclude obtaining such affidavits. Id. at 419-20, 272 P.2d at 721-22.

31. Although there is little discussion of the point, courts apparently will not grant a motion for a new trial on the basis of affidavits which do not conform to the standards applicable on summary judgment motions. Thus, except for Edgar $v$. Finley, in each of the cases cited in notes 28-30 supra, the courts refused to consider the lawyers' affidavits because they were "hearsay." But as Professor Moore quite correctly points out, even the affidavits of witnesses with first-hand knowledge are hearsay. 6A MOORE's FEDERAL PRACTICE, supra note $15, \S 59.08[3]$, at 59-122 n.25. Professor Moore goes on to suggest that "the movant should, if feasible, support his motion with the affidavits of the witnesses as to the proposed new testimony. But if that is not feasible, then we believe that the movant should have the right to submit affidavits of his attorneys . . . as to what the evidence or testimony will be." Id. The argument does not seem to be that the court may then grant the motion on the basis of counsel's affidavit, for Professor Moore goes on to say that "[ $t]$ he impossible or the impractical should not be required at the time the motion is made." Id. The suggestion seems rather simply to be that an affidavit of counsel not made on first-hand knowledge is sufficient to accompany the motion, as provided in FED. R. CIV. P. 59(c), given the 10-day time limit imposed by Rule 59(b). Before the motion may be decided, however, counsel should present competent proof of what the evidence would be. See Krodel v. Houghtaling, 468 F.2d 887 (4th Cir. 1972).

This conclusion is not undercut by the provision in FED. R. Crv. P. 59(d) that the court may grant a new trial on its own initiative "for any reason for which it might have granted a new trial on motion of a party," even for reasons not actually stated in a motion by either party. It is entirely consistent with that provision to maintain that where the court's initiative 
party-either depriving it of the benefit of a verdict or nullifying the chance of a second determination at a new trial.

Attorneys favor the practice of filing their own affidavits for a number of reasons. Counsel often enjoys a relatively global view of the case. Especially where he represents a large entity such as a government agency or business corporation, counsel is likely to be the person best informed about the relevant legal theories and the available facts necessary to support them. Even if other witnesses or even documentary proof can support particular facts, the attorney may alone be able to place those facts in the scheme of his client's case. At trial, a lawyer must adhere to the strictures of competent proof; his global view does not allow him to simply take the stand and tell the whole story as he sees it, no matter how many witnesses and documents the rules of evidence otherwise require.

But at both pretrial and posttrial proceedings, other constraints may tempt attorneys to use their own affidavits, constraints which perhaps ought to affect the permissibility of the practice as well. Time is the most serious of these. In any given case, counsel will have the maximum time for preparation between the filing of the complaint and the trial itself. But the rules of evidence, designed for situations in which attorneys have had such relative luxury, may be inappropriate during the press of pretrial and posttrial proceedings. For instance, the Federal Rules allow a court to issue a temporary restraining order even faster than the nonmoving party can receive notice, or a preliminary injunction as quickly as notice can be given. ${ }^{32}$ Where a party faces irreparable injury, the court may expedite discovery on the basis of an ex parte determination. ${ }^{33}$ And although the court may extend the time for responding to a motion for summary judgment when the necessary affidavits cannot be secured, ${ }^{34}$ in the ordinary case a party opposing a summary judgment motion may have no more than 9 days to marshall his proof. ${ }^{35}$ Similarly, the posttrial motion for a new trial based on extra-record evidence must be served no more than 10 days after the entry of

is based on extra-record facts, proof of those facts must be as substantial as it would have to be had a party moved on that basis.

32. See Fed. R. Crv. P. 65.

33. See, e.g., FED. R. Grv. P. 30(a): "Leave of court, granted with or without notice, must be obtained . . . if the plaintiff seeks to take a deposition prior to the expiration of $\mathbf{3 0}$ days after service of the summons and complaint upon any defendant . . . ."

34. FED. R. Crv. P. 56(f).

35. FED. R. CrV. P. 56(c). 
judgment. ${ }^{36}$

The affidavit practice is fostered, in the second place, by the recognition that at least up to the point at which summary judgment motions are proper, the parties may have no more than information and belief available to substantiate their respective views of the facts; thus courts often expedite discovery, and may even grant interlocutory injunctive relief on that scanty foundation. Given this inevitable relaxation of the usual demand for competent evidence, the attorney, who may have the best sources of information and grounds for belief, becomes an appropriate affiant to advance the ersatz proof.

Notwithstanding the tugs which such forces exert in favor of permitting counsel to participate in pre- (and post-) trial substantive determinations, the practice raises serious ethical and legal problems. The legal profession normally frowns upon lawyers appearing on the stand in their clients' behalf, except as to merely formal or uncontested matters, or in cases where the lawyer's services are of such peculiar value that his withdrawal from the case would seriously harm the client. ${ }^{37}$ Part II demonstrates, however, that the arguments normally posed against attorneys appearing as trial witnesses on the merits may not apply to the more disembodied practice of attorney affidavits.

Yet as Part III shows, even if the practice remains consistent with the demands of professional responsibility, it may often exact a compensating price-the loss of conventional work product protection. Although an attorney's contentions and legal conclusions may be discovered through interrogatories ${ }^{38}$ and requests for admissions ${ }^{39}$ sent to his client, a lawyer is ordinarily entitled to resist inquiry into the way he gathered information, the way he intends to present his case at trial, and-to a more limited extent-the documents not embodying his mental impressions which he has prepared or procured in preparation for litigation. ${ }^{40}$ But when counsel has secured some kind of affirmative relief-expedited discovery, an interlocutory injunction, partial summary judgment or the denial of summary judgment, the grant or denial of a new trial $\longrightarrow$ on the basis of his own sworn statement, the attorney's own credibility and the accuracy of his in-

36. FED. R. Crv. P. 60(b) eases the time pressure by permitting a motion for new trial within 1 year of judgment if the ground for the motion is "mistake, inadvertence, surprise . . . excusable neglect," newly discovered evidence that could not have been uncovered earlier even with due diligence, or fraudulent conduct by the verdict-winner.

37. ABA Code of Professional Responsibility, DR 5-101 \& 5-102.

38. FED. R. Crv. P. 33(b).

39. FED. R. Crv. P. 36(a).

40. See notes 117-34 infra and accompanying text. 
formation necessarily become issues, and the opposing party may be entitled to examine his files and take his deposition to discover what would otherwise be protected information.

Finally, Part IV offers some preliminary guidelines for determining whether the filing of a particular affidavit should entail waiver of work product protection, and what the scope of that waiver should be.

\section{The Question of Professional Ethics}

Although the ABA Code of Professional Responsibility does not directly address the question of attorney affidavits, one element of the Code suggests at least in a preliminary way that the normal constraints on counsel testifying for their clients may not strictly apply to the affidavit practice: The Code explicitly approves a lawyer's verification of his client's pleading. ${ }^{41}$ In verifying statements in a pleading, counsel puts his honesty at stake, particularly since the client has neither prepared those statements nor, in many instances, understood them. ${ }^{42}$ Moreover, by his averment concerning the facts at issue the lawyer plays a role in putting the opposing party to a substantial burden on time and resources. Thus ABA Code recognition of attorney verification may be taken to suggest approval of the affidavit practice in general.

But verification at the pleading stage is far removed from other types of pretrial affidavits. It is not only tolerable but necessary that counsel should be identified with a statement which is necessary to initiate the litigation, but which the client is unable to compose. ${ }^{43}$ It

41. ABA Code of Professional Responsibility, EC 7-25 states that "a lawyer should subscribe to or verify only those pleadings that he believes are in compliance with applicable law and rules."

Verification is still required by many states employing some derivative of the old Code pleading. See note 5 supra. And even though the Federal Rules and their state offspring have dispensed with the requirement of verification, such rules still require the attorney to sign the pleading, and assert that his signature "constitutes a certificate by him that . . . to the best of his knowledge, information, and belief there is good ground to support" the pleading. E.g., FED. R. Crv. P. 11. The Federal Rules dispensed with the requirement of verification largely because it favored the unscrupulous litigant. See R. Millar, Givil Procedure of THE Trial Court in Historical Perspective 173 (1952); 5 C. WRIGHT \& A. MilleR, supra note $9, \S 1333$.

42. See Surowitz v. Hilton Hotels Corp., 383 U.S. 363 (1966). But of. Risinger, Honesty in Pleading and Its Enforcement: Some "Striking" Problems with Federal Rule of Civil Procedure 11, 61 MINN. L. REv. 1, 6 n.16 (1976) (verification may be counterproductive and lead to clients and lawyers passing the buck to each other).

43. See Surowitz v. Hilton Hotels Corp., 383 U.S. 363 (1966); Risinger, supra note 42, at 6 n.16. 
is also true that the strictures imposed before verification or certification may be subscribed are, especially under the Federal Rules, more relaxed than they are at any later point in the litigation: While honesty is demanded, it is far from clear that any duty to investigate is imposed, ${ }^{44}$ and the grounds for information and belief will not be scrutinized too carefully. A correlative consideration is that the necessity for any detailed factual statement is, under most modern schemes, postponed until the discovery stage, with the result that declarations made at the pleading stage have far less binding effect than those made as trial becomes more imminent.

Most attorney affidavits seem therefore to fall inevitably into an uncertain area between the relaxed standards of verification and the strict standards of trial evidence. Analysis of the professional ethics of the affidavit practice thus requires us to consider how the general provisions of the ABA Code concerning attorney testimony bear on the affidavit question. Such analysis ultimately reveals that the affidavit practice deserves greater freedom from the strictures against combining the role of advocate and witness than does actual trial testimony.

\section{A. The Arguments Against Attomey Testimony}

The general position of the ABA Code of Professional Responsibility on attorneys acting as witnesses in their clients' behalf is that:

If, after undertaking employment in contemplated or pending litigation, a lawyer learns or it is obvious that he or a lawyer in his firm ought to be called as a witness on behalf of his client, he shall withdraw from the conduct of the trial and his firm, if any, shall not continue representation in the trial, except that he may continue the representation and he or a lawyer in his firm may testify in the circumstances enumerated in DR 5-101(B)(1) through (4). ${ }^{45}$ Those circumstances, set out in the rule dealing with acceptance of employment in the first instance, are:

(1) If the testimony will relate solely to an uncontested matter.

(2) If the testimony will relate solely to a matter of formality and there is no reason to believe that substantial evidence will be offered in opposition to the testimony.

(3) If the testimony will relate solely to the nature and value of legal services rendered in the case by the lawyer or his firm to the client.

(4) As to any matter, if refusal would work a substantial hardship

44. See 5 C. WRIGHT \& A. Miller, supra note 9, at $\$ 1333$; McCaskill, The Modern Philosophy of Pleading: A Dialogue Outside the Shades, 38 A.B.A.J. 123 (1952).

45. ABA Code of Professional Responsibility, DR 5-102. 
on the client because of the distinctive value of the lawyer or his firm as counsel in the particular case. ${ }^{46}$

The new Disciplinary Rules are essentially a clarification of old Ganon 19 of the Canons of Professional Ethics, ${ }^{47}$ although in one respect the new Code may enunciate a somewhat stricter and more specific test. While the Canons permitted a lawyer to act as witness for his client when it was "essential to the ends of justice," the Code suggests that "doubts should be resolved in favor of the lawyer testifying and against his continuing or becoming an advocate."48

Another provision of the Code prohibits the trial lawyer from attempting to assert his personal knowledge or opinion in argument rather than as a witness:

In appearing in his professional capacity before a tribunal, a lawyer shall not ...

(3) Assert his personal knowledge of the facts in issue, except when testifying as a witness.

(4) Assert his personal opinion as to the justness of a cause, as to the credibility of a witness, as to the culpability of a civil litigant, or as to the guilt or innocence of an accused, but he may argue, on his analysis of the evidence, for any position or conclusion with respect to the matters stated herein. ${ }^{49}$

Although there is little agreement among the commentators about the general purpose of forbidding attorneys to act in a testimonial capacity, ${ }^{50}$ Ethical Consideration 5-9 of the Code of Professional Responsibility does outline the chief arguments in support of the rule:

Occasionally a lawyer is called upon to decide in a particular case whether he will be a witness or an advocate. If a lawyer is both counsel and witness, he becomes more easily impeachable for inter-

46. Id., DR 5-101(B).

47. "When a lawyer is a witness for his client, except as to merely formal matters, such as the attestation of custody of an instrument or the like, he should leave the trial of the case to other counsel. Except when essential to the ends of justice, a lawyer should avoid testifying in court in behalf of his client." ABA CanONS OF PROFESSIONAL Ethics No. 19.

48. ABA Code of Professional Responsibility, EC 5-10; see Frankel, Book Review, 43 U. ChI. L. Rev. 874, 878 (1976) (ABA Code of Professional ResponsibilitY). Provisions rather similar to those in Canon 5 of the new Code are found in the Codes of Trial Conduct promulgated by the American College of Trial Lawyers in 1967 and 1972. See 43 A.B.A.J. 223 (1957) (Article VI); 58 A.B.A.J. 709 (1972) (Article XII).

49. ABA Code of Professional Responsibility, DR 7-106.

50. Perhaps the only principle that would meet general consent is that disqualification does not find its source in any notion of the attorney's incompetence as a witness. See French v. Hall, 119 U.S. 152 (1886); FED. R. EVID. 601; 3 J. WEINSTEIN \& M. BERGER, WEINSTEIN'S EVIDENCE I 601[04], at 601-31 to 601-35; 6 J. WIGMORE, supra note 1, § 6911, at 773-88; Sutton, The Testiffing Advocale, 41 TEx. L. REv. 477, 478-79 (1963); 48 HARV. L. Rev. 140 (1934). 
est and thus may be a less effective witness. Conversely, the opposing counsel may be handicapped in challenging the credibility of the lawyer when the lawyer also appears as an advocate in the case. An advocate who becomes a witness is in the unseemly and ineffective position of arguing his own credibility. The roles of an advocate and of a witness are inconsistent; the function of an advocate is to advance or argue the cause of another, while that of a witness is to state facts objectively. ${ }^{51}$

The first argument is that counsel will hurt his client's case by offering testimony impeachable for interest. Critics have noted that this argument unnecessarily sets attorneys apart from other potentially interested witnesses whose credibility is simply tested on crossexamination. ${ }^{52}$ Moreover, the lawyer will not likely dispel the image of interest by resigning, since he may just as well have become irrevocably biased while representing the client at the earlier stages of litigation or in other legal matters. ${ }^{53}$

The second argument, ironic when paired with the first, is that testimony by an attorney puts his client's opponent at a disadvantage, since the latter will have a hard time attacking the credibility of a lawyer. But any greater weight that the jury might give to this testimony may be due to perfectly legitimate evidentiary considerations: the witness's demeanor in court and standing in his community. In any event, the lawyer's interest in the case is more likely to diminish, rather than enhance, his credibility. ${ }^{54}$ If the Code argument means that opposing counsel's sense of professional fraternity will overcome his partisan duty to his client and cause him to go easy in cross-examination of a fellow attorney, then the rule aims at the wrong lawyer. ${ }^{55}$

The third justification advanced by the Code is that it would be "unseemly and ineffective" for counsel to argue his own credibility. ${ }^{56}$ If ineffectiveness stems from counsel's interest in the case, this argu-

51. ABA Code of Professional Responsibility, EC 5-9.

52. See Enker, The Rationale of the Rule That Forbids a Lawyer To Be Advocate and Witness in the Same Case, 1977 AM. B. Foundation Research J. 455, 457; Comment, The Rule Prohibiting an Altomey from Testifying at a Client's Trial: An Elhical Paradox, 45 U. CiN. L. REv. 268, 270 (1976).

Wigmore asserts that the impeachability argument for disqualification has "totally disappeared from the controversy." $6 \mathrm{~J}$. WIGMORE, supra note $1, \S 1911$, at 775.

53. See Enker, supra note 52, at 457 ; Comment, supra note 52, at 270.

54. See Sutton, supra note 50 , at 480 .

55. See Enker, supra note 52, at 457-58.

56. The same justification would seem to underlie the provision in the American College of Trial Lawyers' Code of Trial Conduct that "if circumstances do not permit withdrawal from the conduct of the trial, the lawyer should not argue the credibility of his own testimony." American College of Trial Lawyers, A Code of Trial Conduct, 43 A.B.A.J. 223, 224-25 (1957). 
ment adds little to the first. On the other hand, if the rule is merely intended to keep lawyers from embarrassing themselves on the stand, it seems superfluous - those who would do so either lack modesty or common sense to begin with or have countervailing reasons for running risk of embarrassment. ${ }^{57}$

The final assertion of Ethical Consideration 5-9 - that the roles of advocate and witness are fundamentally incompatible-reflects what Wigmore characterizes as:

the fear that the testimony of the counsel and his statements in argument might be so identified in the minds of the jury that they would give to the argument a testimonial credit and effect, as if the oath of the counsel as witness were pledged to it, and thus be unduly impressed with its weight. ${ }^{58}$

This basis for the rule does not fit very well with the argument that the testimony of counsel is vulnerable to impeachment. ${ }^{59}$ Nor is it entirely consistent with the suggestion, discussed below, that the public image of the profession will suffer if counsel is permitted to testify. ${ }^{60}$ On the other hand, the point of this argument may really be that, by acting as both advocate and witness, the lawyer himself will become confused, injecting fact or opinion not introduced in evidence into his argument. But it is difficult to see how the attorney's decision to testify increases this danger, which exists whenever counsel is familiar with facts outside the record. ${ }^{61}$

A final argument for barring counsel from testifying holds "not that lawyers as witnesses may distort the truth in favor of the client, but that the public will think they may, and that the public's respect for the profession and confidence in it will be effectively diminished." ${ }^{\prime 62}$ This argument seems to meet with more general agreement

57. See Enker, supra note 52, at $458-59$ (criticizing argument that embarrassment is a factor in attorney testimony as a makeweight obscuring real improprieties involved). But see Sutton, supra note 50, at 481-82 (legal profession is well advised to protect its public image from harsh criticism directed at attorney testimony).

58. 6 J. Wigmore, supra note $1, \S 1911$, at 780 (citing Stones v. Byron, 4 Dowl. \& L. 393, 75 Rev. R. 881 (Q.B. 1846)). A variation on this same argument holds that while the jurors may not give undue testimonial weight to the arguments of counsel, they will evaluate his argument-favorably or unfavorably-by their impression of his integrity and credibility rather than by the force of its reason. Enker, supra note 52, at 457.

59. See Enker, supra note 52, at 462-65.

60. See 6 J. WIGMORE, supra note $1, \S 1911$, at 780 . Quite apart from any such conflict, it has been argued that, stated in these terms, the rule is more appropriately one of trial practice than of professional ethics. Enker, supra note 52, at 461.

61. See Sutton, supra note 50 , at $480-81$.

62. $6 \mathrm{~J}$. WIGMORE, supra note $1, \S 1911$, at $775-76$. Wigmore terms this formulation "the most potent and most common reason judicially advanced." Id. at 776. 
than the others, ${ }^{63}$ but commentators have argued that the professional image is in many instances unlikely to suffer, ${ }^{64}$ especially where there is no independent reason for regarding attorney testimony as intrinsically wrongful. ${ }^{65}$

The absence of a clear scholarly consensus on the arguments opposing attorney testimony should not be taken to suggest the wisdom of the practice. Given the choice, an attorney would make a tactical blunder to offer his own testimony instead of that of an available disinterested witness. That strategic argument alone ensures that the approach does not become commonplace. ${ }^{66}$ No doubt some attorneys may testify either because they succumb to the temptation to falsify or because they simply neglect the standards of competent trial practice. But even if reprehensible in an officer of the court, such obviously dishonest conduct violates explicit provisions of the Code other than the ban on attorney testimony. ${ }^{67}$ The uncertainty of the arguments for barring counsel from the stand does, however, caution against extending the ban indiscriminately to situations where an advocate furthers his client's cause by the more preliminary act of filing an affidavit.

\section{B. The Arguments Applied to the Affidavit Practice}

One of the arguments against attorney testimony is simply irrelevant to affidavits filed by counsel. The danger that a jury will give testimonial weight to the attorney's argument, or will at least be distracted from assessing its logical force, obviously cannot arise, since it will virtually always be the judge who passes on counsel's affidavit. On the other hand, a second argument-that the attorney will himself become confused about the roles of advocate and witness-probably applies with as much force to affidavits as to oral testimony. ${ }^{68}$ Yet as the previous section showed, this is perhaps the

63. See, e.g., Sutton, supra note 50, at 482; Note, The Ethical Propriety of an Allomey's Testifying in Behalf of His Own Client, 38 Iowa L. REv. 139, 146 (1952); Comment, The Altomey as Both Advocate and Witness, 4 CREIGHTON L. REV. 128, 145 (1970).

64. See Comment, supra note 52, at 271.

65. See Enker, supra note 52, at 459.

66. Indeed, one commentator observes that the rule against attorney testimony is more properly one of trial practice than of professional ethics. See id. at 461 .

67. See, e.g., ABA CODE OF PROfessional Responsibility, DR 7-102(A)(2)-(6).

68. That contention seems in fact to have been decisive in Inglett \& Co. v. Everglades Fertilizer Co., 255 F.2d 342, 349 (5th Cir. 1958), where the court stated: "But without impugning any improper professional motive to this obviously able counsel, we doubt that the disposition of patent cases is furthered by counsel being the personal vehicle by which the 'undisputed' facts are put before the Court. We consider it a tribute to the high calling of advocacy to say that we think it an unnatural, if not virtually impossible, task for counsel, in 
most ill-examined contention against attorney testimony in the first place. We are left, then, with a number of arguments against attorney testimony which may apply, although with a different impact, to the affidavit practice.

\section{Counsel's ineffectiveness as a witness.}

The first argument noted above was that a lawyer's testimony on behalf of his client is typically impeachable for interest. No doubt the use of the affidavit form rather than oral testimony does not by itself mitigate the problem of potential or apparent bias. But the danger of impeachability in the case of affidavits may be outweighed by practical problems that do not arise in the case of oral testimony at trial.

The problem of a court misapplying the normal strictures on attorney testimony is illustrated by Inglett $\mathfrak{F}^{\circ} \mathrm{Co}$. v. Everglades Fertilizer Co. ${ }^{69}$ an action for patent infringement. The defendant -Everglades-sought summary judgment on the ground of anticipation by prior art; its motion relied entirely on the affidavit of Samuel Stoll, counsel for defendant, describing the operation of a machine which another company-Arcady Mills-allegedly had in use prior to the grant of the plaintiff's patent. Reversing the district court's grant of summary judgment, the court of appeals expressed its concern that the "inherently unsound practice" of attorney affidavits violated the standards of professional responsibility. ${ }^{70}$ Though the court did not clearly refer to a specific argument in support of the stricture against attorney testimony, ${ }^{71}$ it expressed serious doubt about the factual validity of an affidavit in which the "interstitial argument" of an interested person sought to perform the job of competent testimony. ${ }^{72}$

The Inglett court was correct if it simply meant that Stoll was unlikely to secure a summary judgment with his own affidavit which was impeachable for interest. Stoll's client bore the burden of proof

his own case, to drop his garments of advocacy and take on the somber garb of an objective fact-stater. Certainly we would not reverse a Judge for entering summary judgment merely because some of the papers included argumentative conclusions. But if the "facts' are really facts, they should be put forward as such without interstitial argumentation."

69. 255 F.2d 342 (5th Cir. 1958).

70. Id. at 349-50.

71. "The reason behind the accepted canon on counsel testifying is or may be present, at least tentatively since the Court is put in the position of passing upon the credibility of the contending votaries. Experience proves that the adversary system functions best when the role of Judge, of counsel, of witness if [sic] sharply separated." Id. at 350.

72. Id. at 349-50. 
on the issue of anticipation by prior art, and it would have been unwise, if not improper, for Stoll to use his own affidavit rather than that of some available impartial witness. But the court underestimated the practical exigencies of counsel's position. Stoll may have been unable to secure a similar affidavit from one of the operators of Arcady Mills, for as the court noted:

These participants . . . all . . . seemed genuinely anxious to find out and record all of the pertinent information . . . without unduly imposing on this stranger to the controversy [Arcady Mills]. ${ }^{73}$

And any expert hired by the defendant would likely have been subject to the same disability as Stoll. Given that dilemma, it is difficult to say that Stoll's affidavit was unethical simply because its credibility may have been attacked for interest.

Inglett may seem a peculiar case, but the tight time deadlines generally associated with pretrial motions argue against applying the canons against testimony straightaway to affidavits, despite the common problem of impeachability for interest.

For example, in Douglas v. Beneficial Finance Co. ${ }^{74}$ a Truth in Lending Act class action, defendants moved for summary judgment on April 12, 1971 and on April 19 plaintiffs filed a cross-motion for summary judgment. ${ }^{75}$ Attached to the motion were affidavits of three attorneys, including plaintiff's counsel, who had attended the state court deposition of the manager of one of the defendants. At his deposition-which was apparently untranscribed-the manager had testified about the number of notes transferred for collection to and from his office monthly; the affidavits of counsel were needed to establish the manager's admission. ${ }^{76}$ Though plaintiffs could theoretically have appointed substitute counsel, Federal Rule 56(c) may have given them as little as 10 days to do so. ${ }^{77}$ It is true that at an early stage in the litigation the matter of transfer is more easily effected once substitute counsel can be located, since he will need less time to familiarize himself with the case. But there may simply not be time to find a substitute, particularly in cases where the demand

73. Id. at 345 n.5.

74. 334 F. Supp. 1166 (D. Alas. 1971), rev'd in part on other grounds, 469 F.2d 453 (9th Cir. 1972).

75. Id. at 1169.

76. Id.

77. Under FED. R. Grv. P. 56(f), the court may continue the motion for summary judgment when affidavits are "unavailable" in order that the party opposing the motion may collect his evidence. That may not have helped the plaintiff in Douglas, however, if no one was present at the deposition besides counsel and the witness. It may be, though, that the information was available in documentary form. See Graham v. Pennsylvania R.R., 13 Fed. R. Serv. 943 (S.D. Ohio 1949). 
for preliminary injunctive relief or a temporary restraining order makes hearing and decision of the motion a matter of urgency.

The ABA Disciplinary Rules provide that counsel may act as both advocate and witness at trial "if refusal would work a substantial hardship on the client because of the distinctive value of the lawyer or his firm as counsel in the particular case."78 Although the exception seems mainly intended to justify attorney testimony in cases "where the lawyer has long and intimate familiarity with the details of the matter in litigation,"79 and with the affairs of the client, it may properly apply where the necessity for counsel's testimony arises during trial or so close to the time of trial that the matter of finding a substitute would cause hardship. ${ }^{80}$ Such a reading of the Code suggests that attorneys' affidavits might be proper almost as a matter of course, if not on summary judgment, at least in connection with applications for interlocutory injunctive relief where a delay could result in irreparable harm. And Formal Opinion 339 recognizes that testimony-and presumably a fortiori affidavits-may be proper in connection with posttrial motions because of the attorney's almost irreplaceable familiarity with the case at that point. ${ }^{81}$

A second exception to the bar on attorney testimony-that for testimony on uncontested fact ${ }^{82}$ - may also overcome the impeachability of affidavits in particular cases. In Lula 0 . Sivaco Wire $\mathcal{E}^{\circ}$ Nail $\mathrm{Co}^{83}$ plaintiff mother sued for mental anguish caused by the death of her son in an automobile collision, and plaintiff father sued for loss of consortium and medical expenses occasioned by his wife's emotional disturbance. The defendants moved for summary judgment on

78. ABA CODE of Professional Responsibility, DR 5-101(B)(4).

79. ABA Comm. on Professional Ethics, Opinions, No. 220 (1941).

80. See Erwin M. Jennings Co. v. DiGenova, 107 Conn. 491, 499, 141 A. 866, 869 (1928) (improper to continue as counsel where lawyer "has knowledge that he would be required to be a witness in ample time to have secured other counsel"); Schwartz v. Wenger, 267 Minn. 40, 43, 124 N.W.2d 489, 491 (1963) (counsel should not testify "unless circumstances arise which could not be anticipated"); ABA CoMm. on Professional Ethics, Opinions, No. 339 (1975) (where unanticipated developments made counsel's testimony essential, "it would be manifestly unfair to the client to be compelled to seek new trial counsel at substantial additional expense and perhaps to have to seek a delay of the trial'); American College of Trial Lawyers, $A$ Code of Trial Conduct, 43 A.B.A.J. 223, 224 (1957) (when counsel's testimony first becomes necessary during trial, a substitute should be found only "if feasible and not prejudicial to his client's case').

81. "By the same criterion, a lawyer having knowledge of misconduct of a juror during the trial of a case is not required to withdraw as counsel in the proceedings in order to testify as to facts of which he has knowledge." ABA COMM. ON PROFEssional ETHICs, supra note 80 .

82. ABA Code of Professional Responsibility, DR 5-101(B)(1).

83. 265 F. Supp. 222 (S.D.N.Y. 1967). 
both of those counts, supported by affidavits of their attorneys which stated that plaintiff mother was not involved in the accident and was nowhere in the vicinity when it happened. The court granted summary judgment, since none of the possible choices of law applicable to the case provided recovery for such emotional disturbance when plaintiff was not involved in or endangered by the accident and did not witness the accident. Without even considering the potential ethical impropriety of counsels' affidavits, the court accepted them because it found it apparent from the pleadings and the affidavits that the facts were not disputed. ${ }^{84}$

\section{The difficulty of attacking counsel's credibility.}

The second argument for forbidding counsel to testify at trial is the difficulty the opposing attorney will have in attacking the attorney's credibility as a witness. This argument may be based on the idea that a jury might give undue weight to the testimony of a lawyer, but it is doubtful that the judge, who decides all motions based on affidavits, would be equally impressionable. The law constantly relies on judges to disregard inflammatory, irrelevant, or incompetent evidence. ${ }^{85}$ Their ability to do so should also enable them to avoid inflating the credibility of a lawyer's evidence. ${ }^{86}$

If the point of this argument is rather that opposing counsel will allow his sense of professional fraternity to overcome his duty to his client to challenge adverse evidence, attacking the credibility of his opponent's affidavit presents none of the discomfort of a face-to-face cross-examination. An attorney cross-examining opposing counsel might have to apply such conventional tactics as instilling fear in the witness, ${ }^{87}$ or probing trivial matters when it could be to his advantage ${ }^{88}$ or leading the witness so as to impress his unpleasant demeanor on the factfinder. ${ }^{89}$ But when counsel's testimony appears in an affidavit, the opposing attorney in any event has few opportuni-

84. Id. at 224. Since the affidavits were not made on personal knowledge, they would not ordinarily satisfy the requirements of a motion for summary judgment under FED. $R$. Giv. P. 56(e).

85. See, e.g., Builders Steel Co. v. Commissioner, 179 F.2d 377, 379 (8th Cir. 1950) ("In the trial of a nonjury case, it is virtually impossible for a trial judge to commit reversible error by receiving incompetent evidence, whether objected to or not.").

86. Of course, to the extent that Disciplinary Rule 5-102, see note 2 supra, is grounded on the fear of jury misperception, the argument presented here regarding affidavits would apply with equal force to any form of testimony by counsel, including taking the stand at trial in a nonjury case.

87. See R. Redfield, Cross Examination and the Witness 227 (1963).

88. Id. at 94 .

89. See N. Stevenson, Successful Cross Examination Strategy 204 (1971). 
ties to impeach, obtain admissions, and develop new facts, and so is unlikely even to get the chance to employ abrasive trial techniques.

Finally, the low evidentiary foundation required for most affidavits may make an attack on opposing counsel's sworn testimony much less distasteful than normal cross-examination. Although affidavits filed in connection with motions for summary judgment must ordinarily "set forth such facts as would be admissible in evidence, and . . . show affirmatively that the affiant is competent to testify to the matters stated therein," 90 the same restrictions do not necessarily apply to affidavits filed at earlier and less dispositive junctures in the litigation. No such requirements apply to an attorney's verification or certification of a complaint, which only signifies that "to the best of his knowledge, information and belief there is good ground to support it," 91 and even a motion for a preliminary injunction or a temporary restraining order may be sought on the basis of affidavits filed on information and belief..$^{92}$ An attorney may therefore undermine the affidavit of opposing counsel without impugning his personal integrity or credibility, merely by showing that the witness drew his conclusions on the basis of inadequate information or unfounded, though honest, belief.

\section{The unseemliness of counsel arguing his own credibility.}

Another reason advanced for the rule against counsel acting as witness is that it places him in the "unseemly and ineffective position" of arguing his own credibility. As noted above, ${ }^{93}$ if this justification merely reflects the desire to save counsel from embarrassment, it does not deserve the status of an ethical prescription. Perhaps the underlying premise is that the client will suffer if his attorney avoids reference to his own credibility, rather than subject himself to the immodesty of arguing that potentially significant point in his summation. If so, important ethical differences again arise between the filing of an affidavit by counsel and an attorney's testimony as witness. In the first place, any attack by opposing counsel on the credibility of an affidavit is likely to be rather detached, making any response similarly aseptic. To return to Inglett $\mathfrak{E}^{O}$ Co. v. Everglades Fertilizer $\mathrm{Co}^{94}$ for a moment, plaintiff's counsel would probably have

90. FED. R. Crv. P. 56(e).

91. FED. R. Crv. P. 11.

92. See text accompanying note 13 supra.

93. See text accompanying note $\mathbf{5 7}$ supra.

94. 255 F.2d 342 (5th Cir. 1958); see text accompanying notes 69-73 supra. 
attempted to attack Stoll's affidavit by showing: (1) that Stoll had little experience with machines of the type in question; (2) that Stoll's description of the competing plant's machine was based on observation which lasted perhaps only an hour; (3) that the affidavit contained several mistakes of technical terminology; and (4) that Stoll was being paid on a contingent fee basis, and so had reason to describe the machines' operations as being very similar. ${ }^{95}$ Though the last argument might have caused some discomfort, notably absent would have been any comment on Stoll's appearance, his conduct while testifying, his lack of candor, or any suggestion that he may have recanted a statement on the stand, all of which would have been fair comment had he testified in person..$^{96}$ Stoll himself, in any oral argument before the judge, could confine his argument concerning the credibility of his affidavit to the facts on paper, without mention of his state of mind.

Similarly, since affidavits outside the context of summary judgment may be made on information and belief, ${ }^{97}$ the focus of questions regarding the credibility of such affidavits is removed still further from the character of the witness, to the more objective question of which facts constitute the basis for his information and belief.

\section{The image of the profession.}

Many argue that the image of the legal profession suffers from the public belief that lawyers can and will distort the truth in favor of their clients. ${ }^{98}$ There is no empirical evidence on exactly how the public gains this impression, but presumably, since a trial is a public event, frequently attended by newspeople as well as spectators, word will get out that a certain lawyer testified on behalf of his client, who subsequently won the case. If counsel's testimony were to become a fixture at most trials, people would doubtless begin to suspect that lawyers were not hired solely for their legal skills. But legal and practical limits assure that attorney testimony will always be infrequent. Not only does the hearsay rule guarantee that in the ordinary case counsel will have no competent knowledge of the events in question, but attorneys tend to select disinterested witnesses, if available, purely as a matter of self interest in the typical lawsuit. Furthermore, permitting counsel to testify while continuing his representation does

95. See 255 F.2d at $346-48 \&$ n. 10 .

96. See, e.g., 5 F. Busch, LaW and Tactics in Jury Trials $§ 640$ (1963); J. STEin, GLOSING ARGUMENT $§ 16$ (1969).

97. See notes 14-15 supra and accompanying text.

98. See, e.g., 6 J. Wigmore, supra note $1, \S 1911$, at 775-80. 
not eliminate all ethical sanctions against those inclined to abuse the right to testify. ${ }^{99}$ Thus it is more realistic to discuss the effect on the image of the profession in terms not only of the appearance of truthdistortion to a hypothetical audience, but also of the likely existence or size of that audience.

This perspective clearly distinguishes filing an affidavit from taking the stand. The former activity does not occur in open court, and is much more likely to go unnoticed by those not party to the litigation. Moreover, since the affidavit is usually served on opposing counsel, ${ }^{100}$ it may not even come to the attention of the opposing party, unless he takes more than the usual interest in the details of the litigation. ${ }^{101}$ To be sure, any interested member of the public may secure a copy of the affidavit from the clerk's office where it is on file, and in cases of some significance the fact that counsel submitted an affidavit may appear in the newspapers or in a published opinion of the court. It seems highly unlikely, however, that the public would in general even be aware of the practice.

An attorney is likely to have a more compelling need to file his own affidavit in a nontrial proceeding than to present live testimony at trial. Moreover, in filing an affidavit, the attorney is "participating" in the litigation in a less substantial sense than he would as a trial witness. For these reasons, the attorney affidavit practice should remain relatively free of the general barriers the rules of professional responsibility place before attorneys acting as witnesses in their clients' cases.

\section{A Scheme for Assessing the Ethical Problem}

The preceding section measured the ethics of the affidavit practice against the arguments traditionally advanced against counsel acting as a witness in a case in which he was engaged, and suggested that those arguments applied with less force to situations where an

99. See, e.g., ABA Code of Professional Responsibility, DR 7-102(A)(2)-(6).

100. See FED. R. Crv. P. 5(b).

101. As a practical matter, counsel would not ordinarily send a client copies of every paper filed in an action, nor review them one by one when the client came to the office. Apart from the expense involved, counsel may well conclude that the client's interest is better served by confining discussion to what facts the other side has shown, and how they should be controverted, rather than risk confusing, frustrating, or discouraging an unsophisticated client with the complex and sometimes offensive statements in opposing papers. Even where the papers themselves would be comparatively harmless, detailed review with the client may simply be unproductive use of both his and counsel's time. In either case, then, the existence of an attorney's affidavit would probably be known only by "insiders" to the trial process: counsel for both sides, and the court. 
attorney merely files an affidavit. That discussion demonstrated that some variables may affect the question of propriety to a greater degree than others. For example, where time is short-as it may be on a motion for a temporary restraining order-the courts might look more kindly on counsel's participation than where there is more leisure to secure either substitute counsel or alternate sources of proof. It remains to classify those variables which might assist the court and the practitioner to determine the permissibility of the affidavit practice.

\section{The extent of participation by counsel.}

One element which plainly will cover a wide spectrum is the degree to which the attorney's affidavit draws him into the litigation. The more directly counsel speaks to disputed issues close to the merits of the case, the more significant will be the questions of his credibility and effectiveness as a witness and the impression carried off by the public of the role and character of the profession. While an attorney may enter the litigation in innumerable ways, two in particular warrant attention because of the frequency with which they occur.

The first has to do with authenticating the elements of proof introduced on pretrial motions. By the time of trial the authenticity and custody of most documents which are material to the litigation have been established, without the need for proof, by means of a number of procedural devices. Most simply, it can be done by stipulation of the parties of their own accord. But the Federal Rules also provide that a party may request an admission of the truth of any matter, "including the genuineness of any documents described in the request,"102 if stipulation should prove unavailing. Moreover, Rule 16 allows the court to call a pretrial conference for, among other reasons, the purpose of "obtaining admissions of fact and of documents which will avoid unnecessary proof." 103 But when relief is sought at the pretrial stage, and particularly in cases involving a request for preliminary injunctive relief or a temporary restraining order, the parties may have little time to avail themselves of these advantages; and most often no pretrial conference will have taken place. ${ }^{104}$ Consequently, it frequently happens, especially in cases which rest largely on documentary proof, that disposition of pretrial

102. FED. R. Grv. P. 36(a).

103. FED. R. Grv. P. 16(3).

104. See, e.g., Local Court Rule 1-15, District of Columbia; Pollack, Pretrial Conferences, 50 F.R.D. 451; Murrah, Pre-Trial Procedure, 14 F.R.D. 417, 421; Clark, Objectives of Pre-Trial Procedure, 17 OHIо ST. L.J. 163, 165 (1956). 
motions requires the active participation of counsel, at least to the extent of authenticating the elements of proof. ${ }^{105}$ The Code of Professional Responsibility provides a special exemption for testimony by counsel concerning merely formal matters, including the attestation or custody of an instrument. ${ }^{106}$ In light of the arguments advanced to support the ban on testimony this is not at all surprising; what is significant is that for the reasons just mentioned, the incidence of lawyer-authentication is likely to be far higher in connection with pretrial affidavits than it is at the trial itself. This exception thus provides sufficient justification for a rather large number of instances in which affidavits of counsel will be filed.

A second issue warrants special mention because of the frequency with which ex parte motions will be made prior to trial. ${ }^{107}$ The fact that counsel's affidavit sets forth only uncontested facts obviously provides the strongest indication of its permissibility, ${ }^{108}$ and the Code in such cases permits the even more drastic step of counsel taking the stand as a witness. ${ }^{109}$ Does the fact that ex parte motions are by definition uncontested suffice automatically to bring counsel's affidavit within the Code's exemption?

Undoubtedly the provision in the Code concerning uncontested facts was thought to be justified because with regard to such matters the credibility of counsel's statement is not a part of the factfinder's concern. That being so, nearly all of the arguments against a lawyer taking the stand evaporate. ${ }^{110}$ Even at trial, however, it may happen that counsel's statement, though not contradicted by any direct evidence, is not only material, but sufficiently questionable to create a jury issue, and in such a situation the Code seems to advise against the attorney continuing his representation. ${ }^{111}$ Similar considerations

105. See, e.g., SEG v. Great Am. Indus., Inc., 407 F.2d 453 (2d Cir. 1968); SEC v. Frank, 388 F.2d 486 (2d Cir. 1968); SEC v. General Refractories Co., 400 F. Supp. 1248 (D.D.C. 1975).

106. ABA Code of Professional Responsibility, DR 5-101; id., EC 5-10 \& n.11; see Opinions of the Ethics Committee of the State Bar of Wisconsin, WIs. B. BuLL., December 1974 Supplement, at 54 (Mem. Op. May 16, 1968); N.Y. County Opinion 28 (May 1913).

107. See text accompanying notes $32-33$ supra.

108. See, e.g., Lula v. Sivaco Wire \& Nail Co., 265 F. Supp. 222 (S.D.N.Y. 1967).

109. ABA Code of PROfessional Responsibility, DR 5-101(B)(1).

110. See Sutton, supra note 50, at 491.

111. See id. at 492. Since publication of Professor Sutton's article, Canon 19, which spoke only of testimony about "merely formal matters," see note 47 supra, has been replaced by Disciplinary Rule 5-101(B)(1) \& (2), the first part of which speaks of testimony relating "solely to an uncontested matter," and the second part of which speaks of testimony which "will relate solely to a matter of formality." Unhappily the amendment does little to clarify the ambiguity of the word "uncontested." Ethical Consideration 5-10 states that testimony is 
should govern the approach to affidavits filed in connection with ex parte motions, since the mere fact that there is no opposition by no means indicates that what counsel has to say is unimpeachable. This is not to suggest that such an affidavit is improper altogether, for as the preceding section indicates, the arguments against testimony by counsel are much less persuasive when applied to affidavits. It is only to point out that the affidavit wins no extra points for setting forth uncontested matter.

\section{Type of relief sought.}

One significant difference between testimony by counsel at trial and affidavits filed by counsel in advance of trial is that the latter may at times seek relief which is unrelated to the merits of the litigation. Although it seems a priori evident that that circumstance should make the practice more justifiable, it is perhaps worthwhile to dwell for a moment on the reasons why it should be so. Take by way of example the following case: Company $A$, seeking to avoid a takeover by Company $B$, asks for expedited discovery so that the merits may be resolved before a tender offer is made. Counsel's affidavit will of course address the merits of the case-the likelihood that a tender offer will be made, the injury which will accrue to $A$ 's shareholders if the acquisition goes through, $B$ 's prior history, and so on-but the relief sought is merely procedural, and ought not in any predictable fashion to affect the outcome of the litigation. By far the most significant fact about such a motion is that it is likely to receive only the most cursory attention from the court. It will in virtually all cases be decided without any oral testimony whatsoever, ${ }^{12}$ and may well be decided without oral argument. ${ }^{113}$ Moreover, what argument there is will often be assigned for hearing to a magistrate. ${ }^{144}$

In such a situation there is little force behind the concern that opposing counsel will find it difficult to attack the credibility of a fellow member of the bar. Not only is the statement which itself is at issue reified in the form of an affidavit-thus severely limiting the possibilities of impeachment, obtaining admissions, and developing new facts_-but any attack on the statement under oath may itself be made behind the cover of a document. Worries about the unseemli-

proper concerning "an uncontested issue," and illustrates the point by a footnote which merely quotes old Canon 19. ABA CODE of Professional Responsibilitry, EC 5-10.

112. See, e.g., Local Court Rule 220.8, Northern District of California.

113. See, e.g., Local Court Rule 220.1, Northern District of California; Local Rule 12, Southern District of Illinois; Local Court Rule 1-9(f), District of the District of Columbia.

114. See 28 U.S.C.A. § 636(b)(1)(A) (West Supp. 1978); Local Magistrate Rule 1.01(C)(3), Northern District of Illinois. 
ness of counsel arguing his own credibility dissolve for the same reasons. Finally, the image of the profession is unlikely to suffer any irreparable damage, for at least two reasons in addition to those advanced in the preceding section. First, the public has little interest in the private motion practice which attends discovery, even though the relevant documents may be filed as public records; not even the courthouse benchwarmers are likely to be aware of it. Second, the nature of the relief sought, pertaining as it does simply to the procedure which will govern further conduct of preliminary phases of the litigation, is of a kind which, if the public has any thought at all about it, is probably supposed to be the sole province of the bar anyway.

\section{The foundation necessary to support an affidavit.}

A second crucial distinction between the lawyer's testimony at trial and attorneys' affidavits which has already been alluded to is that the former must be limited to such facts as would be admissible in evidence, while the latter may be filed-except in connection with new trial and summary judgment motions_- on information and belief. This distinction is made necessary not only by the amorphous character of the controversy in the preliminary stages of litigation, but also by the crush of deadlines which loom up far more quickly than the trial date itself; since the pretrial process is prepared to go forward on the basis of an understanding which falls short of that which percipient witnesses would provide, it seems to offer much less justification for disabling counsel from assisting in informing that understanding. In cases where the lawyer's affidavit is made on information and belief, the concern with the difficulty of attacking counsel's credibility is substantially attenuated because the most obvious faults with the attorney's account of things will arise not from any doubts about his personal integrity or credibility, but simply from the likelihood that he drew his conclusions on the basis of inadequate information or unfounded, though honest, belief.

In much the same way, the argument against counsel engaging in the unseemly practice of arguing his own credibility is of far less moment when the focus of questions regarding credibility is removed from the character of the witness to the more objective facts which constitute the basis for his information and belief. Finally, if the solicitude for the image of the profession is bottomed on a fear that the public will act adversely on its perception that lawyers are distorting the truth in favor of their clients, that respect will probably be far less 
diminished if counsel has been forthright about the inherent instability of any statement he makes.

\section{The need for prompt action.}

A final factor which distinguishes the attorney affidavit practice from the lawyer's testimony at trial is the greater frequency with which a party may be faced with quick demands for information to support or oppose requests for relief in the preliminary stages of litigation. Such necessity is and ought to be the mother of subvention in the form of affidavits filed by counsel, at least where it can be shown that any available alternatives would significantly delay the adjudication of an interlocutory motion. Disciplinary Rule 5-101(B)(4) provides that counsel may act as both advocate and witness at trial "if refusal would work substantial hardship on the client because of the distinctive value of the lawyer or his firm as counsel in the particular case,"115 and there are indications that it may properly be applied where the need for counsel's testimony at trial arises suddenly. ${ }^{116}$ The analogy is far from perfect, since the matter of finding adequate substitute counsel becomes far harder as trial nears.

But whatever damage attorney testimony may cause, substitution of counsel after the damage is done seems pointless. Even if it is unseemly for a lawyer to argue his own credibility, the unseemly effect is not remedied by the substitution of a fresh lawyer once the argument has taken place. Similarly, any apprehension about role confusion caused by the attorney acting as witness cannot be quieted simply by leading the muddled attorney away after he has infected court and opposing counsel with his bewilderment. And even if opposing counsel feels loathe to attack the testifying advocate (perhaps out of fear the assault will be returned), that too may persist unless it is clear before argument of the motion that the attorney-witness is stepping out of the case.

\section{The Work Product Doctrine and AfFidavits of COUNSEL}

\section{A. Work Product Protection and Its Underpinnings}

Rule 26(b)(3) of the Federal Rules of Givil Procedure sets forth the essential rules for protection of materials prepared by parties, their attorneys, and their agents in anticipation of litigation or for

115. ABA Code of Professional Responsibility, DR 5-101(B)(4).

116. See note 80 supra and accompanying text. 
trial. ${ }^{17}$ Under the rule, a party seeking discovery of such work product must show both "substantial need of the materials in the preparation of his case" and an inability "without undue hardship to obtain the substantial equivalent of the materials by other means." 118 If the court ultimately orders discovery in response to such a showing, it must protect against disclosure of the attorney's "mental impressions, conclusions, opinions, or legal theories." 119 While the rule is designed to prevent harmful invasions of the attorney's private preparations for trial, its scope does not extend beyond attempts to obtain discovery of documents and other tangible things. ${ }^{120}$

Although the rule does not take full account of the fact, different types of information will by and large be more deserving of protection than others, and the justifications for applying the work product rule will vary according to what information is sought. Different principles may apply, for example, to a request for survey data prepared in anticipation of litigation than would to a request for factual

117. The present rule was enacted as part of a general reorganization and amendment of the discovery rules in 1970. For the background to these amendments, see Proposed Amendments to the Federal Rules of Civil Procedure Relating to Discovery, 48 F.R.D. 487. The amendments were enacted by order of the United States Supreme Court in 1970. 398 U.S. 979 (1970). The text of subsection (b)(3) reads in pertinent part: "[A] party may obtain discovery of documents and tangible things otherwise discoverable under subdivision (b)(1) of this rule and prepared in anticipation of litigation or for trial by or for another party or by or for that other party's representative (including his attorney, consultant, surety, indemnitor, insurer, or agent) only upon a showing that the party seeking discovery has substantial need of the materials in the preparation of his case and that he is unable without undue hardship to obtain the substantial equivalent of the materials by other means. In ordering discovery of such materials when the required showing has been made, the court shall protect against disclosure of the mental impressions, conclusions, opinions, or legal theories of an attorney or other representative of a party concerning the litigation." FED. R. Grv. P. 26(b)(3).

The subsection goes on to excuse the required showing with regard to a demand by a third person-party or witness-for a copy of a statement which that person made concerning the action. Id.

For general discussions of work product, see Cooper, Work Product of the Rulesmakers, 53 Minn. L. Rev. 1269 (1969); Developments in the Law-Discovery, 74 HARv. L. Rev. 940, 1027-46 (1961) [hereinafter cited as Discovery Developments].

118. FED. R. CrV. P. 26(b)(3); see note 117 supra.

119. FED. R. Crv. P. 26(b) (3); see note 117 supra.

120. When information concerning trial preparation is sought under other provisions of the Federal Rules of Civil Procedure-including Rule 30 (depositions upon oral examination), Rule 31 (depositions upon written questions), Rule 33 (interrogatories to parties), and certain subsections of Rule 45 (subpoenas) - protection must be sought in the uncodified work product doctrine of Hickman v. Taylor, 329 U.S. 495 (1947), and the general protective provisions of Rule 26 (c). The latter gives federal judges the power, upon motion by any party from whom discovery is sought, to "make any order which justice requires to protect a party from annoyance, embarrassment, oppression, or undue burden or expense," including an order "that certain matters not be inquired into, or that the scope of the discovery be limited in certain matters." FED. R. CrV. P. 26(c). 
information useful for impeaching one's own or the opposing party's witnesses. Nonetheless there is value in canvassing in gross the arguments in support of the work product doctrine before considering the application of that notion in cases where counsel has filed an affidavit.

The Advisory Committee's Note to Rule 26(b)(3) summarizes the four major justifications underlying attorney work product protection. ${ }^{121}$ First and perhaps most intuitive is the belief that it would be inherently unfair for one party automatically to have access to the fruits of another party's preparatory labors, ${ }^{122}$ that a party, in effect, has a proprietary interest in its work product.

A second notion, related to the first but more sophisticated, is that elimination of work product protection would discourage pretrial preparation by all parties. ${ }^{123}$ On the one hand, slothful attorneys would forego their own trial preparation, relying instead on discovery of opposing counsel's trial preparation materials. On the other hand, attorneys who would normally conduct thorough pretrial investigations would be discouraged from doing so, fearing that they would merely be finding, memorializing, and ultimately revealing holes in their own cases. ${ }^{124}$ In the end, the presentation of issues at trial would be insufficiently sharpened by the adversary system to allow accurate and fair resolution of the controversy. ${ }^{125}$

A third argument for the work product doctrine stresses the need to protect attorneys from discovery of memoranda based on their rec-

121. See Proposed Amendments to the Federal Rules of Civil Procedure Relating to Discovery, Advisory Committee Note, 48 F.R.D. 487, 501. One justification advanced in the Advisory Committee Note to Rule 26(b) (3)-avoiding the danger of "sharp practices"-is not treated in any depth in this article. Such "sharp practices" might range from simple deceit about what had in fact been discovered, see Gardner, Agency Problems in the Law of Attomey-Client Privilege: Privilege and "Work Product" Under Open Discovery (pt. 2), 42 U. DET. L.J. 253, 269 (1965), to "red herrings in the form of false statements or misleading briefs or memoranda . . . inserted in the file for the purpose of misleading the opposition." Cleary, Hickman v. Jencks: Jurisprudence of the Adversary System, 14 VAND. L. REV. 865, 869 (1961). But as one commentator has persuasively argued, "[t] he paucity of comment in this area reflects the lack of importance of the anticipated danger of evasion, which of itself furnishes no more reason for limiting discovery of trial preparation materials than any other kind of information." Cooper, supra note 117 , at 1276 .

122. See 48 F.R.D. at 501. A similar suggestion is made in Justice Jackson's concurring opinion in Hickman: "Discovery was hardly intended to enable a learned profession to perform its functions either without wits or on wits borrowed from the adversary." 329 U.S. at 516.

123. See 48 F.R.D. at 501.

124. See Sano Petroleum Corp. v. Shell Oil Co., 3 F.R.D. 467, 468 (E.D.N.Y. 1944); Gardner, supra note 121, at 271 n.300; Taine, Discovery of Trial Preparations in the Federal Courts, 50 Colum. L. Rev. 1026, 1047 n.131 (1950); Discovery Developments, supra note 117, at 1029.

125. See Discovery Developments, supra note 117, at 1029. 
ollection of oral interviews. ${ }^{126}$ The Supreme Court observed in Hickman $v$. Taylor ${ }^{127}$ that "[w]ere such materials open to opposing counsel on mere demand, much of what is now put down in writing would remain unwritten." ${ }^{128}$ While this point is related to the general danger of inadequate preparation noted above, ${ }^{129}$ Hickman warns more specifically that discovery of counsel's notes of what a witness told him could easily lead to the discovering party putting counsel on the stand to force him to impeach his own witness, ${ }^{130}$ a practice Justice Jackson condemned as "out of professional character" for the lawyer. ${ }^{131}$

A final justification for work product protection-and perhaps the most difficult to define-is the need to shield from discovery each side's informal evaluation of its case ${ }^{132}$ to protect what has been called "hard-core" work product. ${ }^{133}$ Although the Federal Rules do not excuse withholding facts or legal theories, counsel's assessment of the strength of his case, as well as his strategy for adducing proof at trial-the questions to be put to witnesses, the order in which they are to be called, the cases relied on as support for a legal contention-must be guarded to preserve a desirable element of surprise and to prevent a discovering party from undertaking a point-bypoint obfuscation of its opponent's case. ${ }^{134}$

126. See 48 F.R.D. at 502.

127. 329 U.S. 495 (1947).

128. Id. at 511 .

129. See text accompanying notes 123-24 supra.

130. "Under ordinary conditions, forcing an attorney to repeat or write out all that witnesses have told him and to deliver the account to his adversary gives rise to grave dangers of inaccuracy and untrustworthiness. No legitimate purpose is served by such production. The practice forces the attorney to testify as to what he remembers or what he saw fit to write down regarding witnesses' remarks. Such testimony could not qualify as evidence; and to use it for impeachment or corroborative purposes would make the attorney much less an officer of the court and much more an ordinary witness. The standards of the profession would thereby suffer." 329 U.S. at 512-13.

131. Id. at 517.

132. See 48 F.R.D. at 501.

133. See Cooper, supra note 117 , at $1283-301$.

134. See id. The American Bar Association has provided a useful catalogue of the types of information which would be protected under this rationale in civil trials: "notes or outlines of trial strategy, of arguments to be made, of authorities to be cited, and of questions to be asked witnesses; also memoranda between personnel in the office on legal questions, evidence, prospective jurors, or other aspects of the case except medical, scientific, and experts' reports ... , records of an attorney's travels with respect to a case; summaries and analyses of the case file, evaluations of anticipated witnesses or their testimony; evaluations of the probabilities of obtaining certain evidence; investigative sources and techniques." ABA PROJECT ON Minimum Standards for CRiminal Justice, STandards Relating to Discovery and Procedure Before Trial 91 (1969). 


\section{B. Work Product Principles and Their Application to Attorney Affidavits}

The kinds of affidavits counsel may file are numerous and varied, and the considerations germane to the practice are correspondingly complex. Beginning with one particular type of affidavit as an example therefore may help focus an analysis of the affidavit practice in the light of the traditional justifications of work product protection. This section relies on the example of an affidavit signed and filed by an attorney in support of a plaintiff's motion for a preliminary injunction. Let us suppose that the affidavit includes allegations based on the attorney's information and belief, derived principally from an interview the attorney has had with a key witness. The press of time makes it impossible to secure the affidavit of the witness himself, but the court grants the preliminary injunction anyway, relying solely, or in part, on the attorney's affidavit. If the defendant then notices the deposition of plaintiff's attorney, and requests in a subpoena duces tecum that the attorney bring with him to the deposition all documents, memoranda, briefs, correspondence, and notes relevant to the contentions in his affidavit, the question becomes whether and to what extent the attorney has lost work product protection by filing his affidavit.

As we will see in Part IV, we have already loaded the question a bit by specifying a particular type of affidavit at a particular stage of litigation: Certain elements peculiar to preliminary injunction motions may actually stand for variables in the calculus that Part IV will recommend for determining the extent of work product waiver. Nevertheless, when tested against the normal justifications for work product, the affidavit in support of the injunction motion strongly suggests that the attorney affidavit practice entails considerable work product waiver.

\section{The "proprietary" claim for work product protection.}

Unlike the other justifications for the work product doctrine, the notion that a party has a proprietary right to its work product does not look to the effect that granting discovery will have on the later course of the litigation. It is at best a vague equitable argument, akin to Aesop's fable of the grasshopper and the ant: Somehow it seems unfair if "one side should . . . automatically have the benefit of the detailed preparatory work of the other side."135 This principle is unconvincing even in cases where counsel has filed no affidavit, since it defies the most elementary principle of discovery rules-that a party 
should not profit from its adversary's helpless ignorance. ${ }^{136}$ But even if there is some life in the intuitive appeal of the proprietary principle, there seems equal and countervailing appeal in the idea that by injecting his own perception of the facts into the litigation, and especially by securing affirmative relief on the basis of that perception, counsel has secured just compensation for the appropriation of his "property." Equally significant is the fact that the statement given by the key witness to counsel may contain adverse evidence or impeachment material. Although any inaccuracies in the witness's account might be corrected at trial through cross-examination, that possibility does not exist where the information has been filtered through the attorney's affidavit. And the fact of outstanding injunctive relief based on an inaccurate factual premise points toward permitting the most rapid means available for ascertaining the whole truth, even though that might entail discovery of counsel's notes. These counter-arguments suggest no specific guidelines for work product waiver, but they propel us into the more serious arguments for work product protection with some momentum towards finding waiver.

\section{The trial preparation argument.}

As noted above, the trial preparation argument has two facets: Discovery of work product will tempt the lazy attorney to rely on his opponent's preparation and discourage even the diligent attorney from thorough pretrial investigation. ${ }^{137}$ The first argument seems questionable in any context. It hardly seems realistic to suppose that an attorney would adopt a wait-and-see approach instead of trying to conduct his own interview of a percipient witness. While counsel's notes might contain some statements that could be used to discredit his own witness, opposing counsel would be foolish to gamble on this possibility; overriding incentives favor independent preparation. As one commentator has observed, a party:

must know the facts as they are likely to appear at trial to make a useful evaluation of the case for settlement and trial purposes, and he will not risk trial without such preparation. Moreover, he will be unwilling to let his adversary get to the witnesses first if this can

136. "The authors of the Federal Rules consequently intended to use discovery to reform the adversary system; they intended litigation to proceed with both sides in full possession of all facts and with each aware of the other's tactical strengths and weaknesses." W. Glaser, Pretrial Discovery and the AdVersary System 30 (1968); see Cooper, supra note 117 , at 1274 .

137. See notes 123-24 supra and accompanying text. 
be helped, since the first approach may give valuable psychological advantage even where all parties are acting in good faith. ${ }^{138}$

If the opposing party fails to undertake independent investigation, the reason is more likely to be "lack of means or opportunity than . . . a calculated choice to depend on disclosure of the adversary's investigation." 139

But the argument seems even weaker when one attorney files an affidavit which enables him to obtain a preliminary injunction. So long as courts limit discovery to materials supporting an attorney's affidavit, ${ }^{140}$ no opposing counsel could safely afford to gamble that such an affidavit would actually be filed. And unless trial preparation materials generated by the attorney after entry of the court's order would themselves lose protection by the filing of the prior affidavit, continued investigation by the plaintiff between the order and trial would also counteract the tendency toward laziness in one who had secured only part of his opponent's files.

Moreover, if the court has relied heavily on hearsay statements recited in the attorney's affidavit, counsel for the enjoined party should have the right to inspect the notes on which the affidavit (and thus the relief) was based. ${ }^{141}$ Even when the extent of the attorney's use of a witness's statement and the court's reliance on it are less clear, discovery should still be permitted. The risk that injunctive relief may ultimately be based on an inaccurate factual premise points toward permitting the most rapid means available for ascertaining the facts, so as to prevent gratuitous harm to an unjustly enjoined party. ${ }^{142}$

The second facet of the trial preparation argument is that if the opposition can obtain counsel's notes of an interview with a percipient witness, counsel will be deterred from seeking such statements, for fear of finding, memorializing, and revealing holes in his own case. Once again, as noted above, ${ }^{143}$ the risks involved are sufficiently great that that fear is unlikely to deter investigation even in

138. F. James, Civil Procedure 206 (1965); see Cooper, supra note 117, at 1280.

139. F. JAMES, supra note 138, at 207.

140. See notes $183-86$ infra and accompanying text.

141. Even if it cannot be shown affirmatively that the judge gave weight to the account of the witness's statements given in the attorney's affidavit, the attorney's demonstrated belief in its importance to the question of irreparable harm defeats any argument that protecting it is necessary to ensure trial preparation.

142. Indeed, the whole case may ultimately hinge on grant or denial of the preliminary injunction. See FED. R. Grv. P. 65(a)(2) ("[T]he court may order the trial of the action on the merits to be advanced and consolidated with the hearing of the application [for a preliminary injunction].").

143. See notes 138-39 supra and accompanying text. 
the ordinary case. But where the client would fear irreparable harm if an injunction were not granted, a rule that counsel's notes of witness statements are fair game only after affirmative relief has been secured is almost certain to have no deterrent effect.

If we are postulating a rule that the attorney's notes are discoverable only after the attorney has employed them to get some affirmative relief, the more difficult issue would seem to be whether counsel has in fact "employed" the statements in securing interlocutory relief. If the affidavit specifically sets out the statements it might be reasonable to presume the question already answered, although even there it would often be unclear whether the judge gave any weight to such hearsay. But since the real question is preparation-deterrence, inclusion in the affidavit itself indicates the attorney's belief that the information bears importantly on the question of irreparable harm, and for that reason ought to settle the matter. But if the affidavit makes no specific reference to the statements the issue is slightly more complex. The reason for failure to include may be one or more of several: Fear of himself becoming a witness, irrelevance to the issue, or even the fact that the statements point away from the relief being sought. The first will be addressed below. But with respect to the second and third, the preparation-deterrence question is clearly a false one, since irreparable harm can be avoided before production can be required. The attorney is unlikely to try to increase the chances of victory at trial on the merits by avoiding discovery of unfavorable evidence, when lack of preparation will correspondingly diminish the chance of success at the stage of preliminary relief, and when the likelihood of having to turn over unfavorable information anyway is modest. One might therefore suggest that the right of discovery should turn on the fact that a preliminary injunction has been issued, and not on the fact that counsel secured it in part by use of his own affidavit. But the answer furnished by Rule 26(b)(3) seems clear: If we start by accepting the trial preparation justification in the ordinary run of cases, counsel's affidavit becomes the crux of the matter. For the rule requires a showing of "substantial need" and of inability to obtain the "substantial equivalent of the materials by other means." And the notes are "needed" precisely because it is imperative to check the accuracy and credibility of counsel's statement.

It might be argued that even if permitting a defendant to discover the plaintiff's attorney's notes would not deter investigation altogether, it might encourage the plaintiff's attorney to omit 
recording facts favoring the other side. Again, this concern seems illusory.

A party needs written statements signed by the witnesses to tie them down to their early, presumably unrehearsed, versions of the occurrence, and this purpose contemplates the possible use of a statement at trial for impeachment purposes if a witness should change his story. But if it appears at trial that the investigator omitted from the statement unfavorable facts which the witness told him, then the value of the statement is likely to be destroyed and the investigator's side seriously prejudiced in the eyes of the trier of fact. ${ }^{144}$

And once again the marginal benefit of using undiscoverable written notes to secure preliminary relief probably outweighs the cost of thereafter having to turn over the notes to the other side.

\section{The undesirability of attorneys serving as witnesses.}

The third argument against discovery of work product holds that if the plaintiff's attorney is forced to produce his recollection (whether orally at his deposition or in the form of notes he has taken) of the witness's statements to him, the witness's testimony at trial might in many instances differ from the attorney's recollection. Forcing the attorney to testify to the witness's prior inconsistent statements would require him to choose between maintaining his own credibility and furthering his client's interests. ${ }^{145}$ Such a choice might undermine the client's confidence in the attorney's partisanship, interrupt the attorney's control over the conduct of the case, and relegate the attorney to the status of a participant. ${ }^{146}$

In any proceeding, a discovering attorney could bring his opponent's work product notes into evidence only by putting the opposing attorney himself on the stand. The rules of evidence make an attorney's notes of conversations with witnesses double hearsay that can be used only if the attorney offers contradictory testimony on the stand. ${ }^{147}$ The Federal Rules of Civil Procedure permit the use of an

144. F. JAMES, supra note 138, at 206; see Southern Ry. v. Lanham, 403 F.2d 119, 129 (1968); Cooper, supra note 117, at 1277-78.

145. One commentator suggests that the ticklish problems raised by counsel's taking the stand can often be resolved by a stipulation that counsel would have testified to a particular fact. $3 \mathrm{~J}$. WEINSTEIN \& M. BERGER, supra note 50, at \ 601[04]. The very infrequency with which counsel actually is called to the stand, see United States v. Maloney, 241 F. Supp. 49 (W.D. Pa. 1965), indicates that such stipulations are common practice. Indeed, the dearth of cases suggests that this argument for work product is generally weak.

146. Discovery Developmenis, supra note 117, at 1029.

147. See, e.g. , Fed. R. Evid. 801(d)(1); MODEL Code of Evidence 503(b) (1942); UnIFORM RULE OF EVIDENCE 801(d)(1). 
attorney's deposition only under similar limitations. ${ }^{148}$ In any event, the danger of the attorney being forced to take the stand flows naturally from the rule that a party may discover notes of attorney interviews with witnesses by showing substantial need and the absence of equivalent substitute materials. ${ }^{149}$

The question, then, is whether this objection-which is really only a qualified argument for work product-applies with even less force when an attorney files an affidavit. The answer seems fairly clear. First, even if the attorney who filed the affidavit is forced to take the stand, his testimony is not likely to shake his client's confidence in his loyalty to the client's case, since he has already demonstrated that partisanship by taking the unusual step of filing an affidavit, which-presumably-presented all facts in a light most favorable to the client. Moreover, having gained the benefit of a preliminary injunction on the basis of the affidavit, the client cannot complain if its attorney is put on the stand at trial to tell the rest of the story. Finally, the attorney who has filed an affidavit has little reason to fear that he will be forced to choose between his own credibility and that of the witnesses on whom he relied, when the latter would be more beneficial to the client. This is not the ordinary case of counsel and witness taking contradictory positions. The affidavit presumably will be consistent with any testimony subsequently given by the witnesses at trial. And the attorney can always minimize the importance of or emphasize the ambiguity of his notes. This is not to suggest that the self-interest of an attorney who has filed an affidavit automatically coincides with the client's interest. Rather, the attorney who participates in the case by filing an affidavit is likely to have already addressed and reconciled any conflicts in credibility between himself and his witnesses.

\section{The need to shield trial strategy.}

Professor Cooper has characterized this last justification for the work product doctrine as the "hard-core" of an otherwise rather insubstantial notion. ${ }^{150}$ Essentially it is that while under the revised Federal Rules there is no excuse for withholding legal or factual contentions, the method by which counsel intends to prove his case at trial-the questions to be put to witnesses, the cases to be relied on as support for a legal contention, the order in which witnesses are to be

148. See FED. R. Crv. P. 32(a)(1).

149. See notes 117-20 supra and accompanying text.

150. Cooper, supra note 117 , at 1269. 
called, counsel's evaluation of the strengths and weaknesses of the case-should be guarded in order to preserve a desirable element of surprise and to prevent an adversary from undertaking a point-bypoint obfuscation at the proof-making stage. It should be clear that the issue arises only in an indirect fashion with regard to statements taken from witnesses. It is put most pointedly when discovery is sought of an attorney's intraoffice memoranda outlining trial plans and notes of legal research. Nonetheless it may well be an element in our hypothetical if, for example, counsel's notes of statements made by witnesses were interspersed with comments concerning their desirability as witnesses, points to emphasize or soft-pedal at trial, case references, or suggestions concerning the weight to be given a particular theory at trial. Rule 26(b)(3) indicates that "[i]n ordering discovery of [trial preparation] materials when the required showing has been made, the court shall protect against disclosure of the mental impressions, conclusions, opinions, or legal theories of an attorney ...." And apparently the protection which is to be extended to such information is intended to be absolute; if a particular document is otherwise discoverable, hard-core work product should be excised by the court after in camera review. ${ }^{151}$ Perhaps the most difficult question presented by the filing of an affidavit by an attorney is whether the protection usually given hard-core work product is thereby waived.

The nonabsolute character of "hard-core" work product. Despite the apparently absolute prohibition in Rule 26 against disclosure of counsel's mental impressions, conclusions, opinions, and legal theories, it is fairly well established that the protection may be lost in several types of cases. Most obviously, protection should be waived when an attorney is actively involved in the transaction at issue in the litigation, and seeks to withhold documents dealing with his activities. ${ }^{152}$

151. Duplan Corp. v. Moulinage et Retorderie de Chavanoz, 509 F.2d 730, 736 (4th Cir. 1974), cert. denied, 420 U.S. 997 (1975); Xerox Corp. v. I.B.M., 64 F.R.D. 367, 381 (S.D.N.Y. 1974); Glower v. Walters, 51 F.R.D. 288, 289 (S.D. Ala. 1970); 8 C. WRIGHT \& A. MILLER, supra note 9, at $§ 2026$.

152. See 4 MOORE'S Federal PRACTice, supra note 15, I 26.64[4], at 26-447; $q$. Bourget v. Government Employees Ins. Co., 48 F.R.D. 29 (D. Conn. 1969) (attorney for insurance company, which failed to settle within policy limits, had information bearing on bad faith and recklessness); LaRocca v. State Farm Mut. Auto. Ins. Co., 47 F.R.D. 278 (W.D. Pa. 1969) (attorney for insurance company which failed to settle within policy limits subject to discovery; file of plaintiff's attorney in former action not discoverable); Kearney \& Trecker Corp. v. Giddings \& Lewis, Inc., 296 F. Supp. 979 (E.D. Wis. 1969) (counsel purportedly involved in fraud on patent office, a defense to infringement action); Kirkland v. Morton Salt Co., 46 F.R.D. 28 (N.D. Ga. 1968) (malicious use of process in former action); Rekeweg v. Federal Mut. Ins. Co., 27 F.R.D. 431 (N.D. Ind. 1961) (action against attorney for failure to sue 
Related issues frequently arise in cases where discovery is sought from an attorney who is an officer or director of a corporate party. ${ }^{153}$ But it is difficult to apply such cases straightforwardly to the affidavit practice, since the mere filing of an affidavit involves the attorney not as performer but as witness who might not have first-hand information.

A second class of cases recognizing a waiver of otherwise absolute protection encompasses situations in which the attorney has disclosed work product information to third persons who stand in an adversarial relation to the attorney's client. The explicit language of Rule 26(b)(3) would foreclose any waiver argument where the person to whom disclosure is made may be considered an agent of counsel or his client, and cases decided even before the 1970 amendments recognized the need for communication between an attorney and persons with whom he was aligned in interest. ${ }^{154}$ For the same reason, protection is most often afforded to communications between attorneys for coparties. ${ }^{155}$ But when disclosure is made under circumstances which make it likely that the information will fall into the hands of an opposing party, protection is said to be waived. The explanation is, of course, obvious: If the function to be served by this qualified immunity from discovery is the preservation of some element of spontaneity and surprise in the presentation and argument of cases at trial, disclosure will either indicate that the attorney who might claim the privilege thinks the information unimportant to his trial strategy, or mean that the purposes of the rule can no longer be served by nondiscoverability.

The relevance of these cases to the attorney's affidavit is obvious, although their implications for increased discoverability are limited. Revelation of mental impressions, opinions, conclusions, and theories

within statute of limitations); Gulf Constr. Co. v. St. Joe Paper Co., 24 F.R.D. 411 (S.D. Tex. 1959) (attorney involved in process of mitigating damages).

153. See Kearney \& Trecker Corp. v. Giddings \& Lewis, Inc., 296 F. Supp. 979 (E.D. Wis. 1969) (production of documents ordered even though they involved activities of counsel both inside and outside corporate structure); Smith v. Bentley, 9 F.R.D. 489 (S.D.N.Y. 1949) (position as officer or director in itself is not enough); Stone v. Grayson Shops, Inc., 8 F.R.D. 101 (S.D.N.Y. 1949) (discoverability depends on capacity in which attorney was acting when he received the information; in this case discoverable even if acting as attorney).

154. See, e.g., Natta v. Zletz, 418 F.2d 633 (7th Cir. 1969) (communications between outside and house patent counsel; communications between counsel and retained expert).

155. See, e.g., Smith v. Bentley, 9 F.R.D. 489 (S.D.N.Y. 1949). See generally 4 MOORE's Federal PRACTICE, supra note 15, ๆ 26.64[4], at 26-447 \& n.16; 8 C. WRIGHT \& A. MilleR, supra note 9, at § 2024; Gardner, supra note 121, at 290; Discovery Developments, supra note 117, at $1044-45$. 
in an affidavit indicates-even more obviously than does disclosure to a third person-a waiver of the privilege as to the information disclosed, since a copy of the affidavit is served on opposing counsel. ${ }^{156}$ But it is difficult to infer from that disclosure a right to go behind the affidavit to supporting materials and thoughts: To the extent that hard-core work product contained in such form remains obscure after service of the affidavit, it is difficult to say that the attorney-affiant thinks it unimportant to trial strategy, or that the purposes of the rule can no longer be served by nondiscoverability.

The "prior use" exception. Although the Supreme Court has not considered the question in connection with genuine hard-core work product, it indicated in United States $v$. Nobles ${ }^{157}$ that a party may lose protection of other trial preparation materials once it makes "testimonial use" of them in the course of litigation. Nobles was tried for armed robbery of a federally insured bank, and at trial attempted to impeach two prosecution witnesses by offering the testimony of an investigator to whom they had made statements. The essence of those conversations was preserved in the investigator's written report, which the district court ordered produced as a condition of the investigator's testifying. When Nobles's counsel declined to produce the report, the court refused to permit the investigator to testify. Nobles was convicted, and the Supreme Court ultimately held that production was properly made a condition of the investigator's testifying.

Although the issue arose in the context of a criminal trial, the Court recognized that the work product doctrine "applies to criminal litigation as well as civil."158 And as is true in civil actions under Federal Rule of Civil Procedure 26(b)(3), the Court noted that the doctrine protects material prepared by agents for the attorney as well as those prepared by the attorney himself. Nor does the protection dissipate once trial is begun, since "[d]isclosure of an attorney's efforts at trial, as surely as disclosure during pretrial discovery, could disrupt the orderly development and presentation of his case."159 Whatever might otherwise be the case, however, "where . . . counsel attempts to make a testimonial use of these [work product] materials the normal rules of evidence come into play with respect to cross-

156. See Fed. R. CIv. P. 5(a).

157. 422 U.S. 225 (1975).

158. Id. at 236. Where discovery is sought by the defendant from the prosecution in a criminal case, of course, the question is a bit muddied by the Jencks Act, 18 U.S.C. $\S 3500$ (1976).

159. 422 U.S. at 239. 
examination and production of documents." 160

It should not be supposed that by use of the phrase "testimonial use" the Court meant to indicate that waiver attaches only when the materials themselves are introduced in evidence. In fact, the only actual evidentiary use made of the investigator's notes occurred when they were shown to one of the prosecution witnesses to refresh his recollection of his conversation with the investigator; ${ }^{161}$ and that alone was not enough to trigger disclosure of any remaining relevant material. Nor was there any indication that the investigator had referred to the notes or would refer to them on the stand as past recollection recorded or as refreshment of present recollection. Rather, what the Court seems to have had in mind was merely the fact that once the investigator had testified, they would become relevant to the subject matter of his direct examination.

Respondent can no more advance the work-product doctrine to sustain a unilateral testimonial use of work-product materials than he could elect to testify in his own behalf and thereafter assert his Fifth Amendment privilege to resist cross-examination on matters reasonably related to those brought out in direct examination. ${ }^{162}$

The reasons for ordering disclosure in those circumstances are fairly obvious. The very notion of cross-examination presumes that the witness may present simply half-truths; the role of opposing counsel is then to discover and present the remaining and qualifying circumstances concerning the subject of testimony, and the facts which diminish the personal trustworthiness of the witness. And while both elements may be supplied from other sources, there is no equally effective substitute for having the witness supply his own refutation immediately following his direct examination. ${ }^{163}$ Thus the investigator's report becomes testimonial material once he has taken the stand in the obvious sense that it then is evidence, which can be employed by

160. Id. at n.14. Conclusions similar to that reached by the Court in Nobles have been arrived at by a number of lower courts in civil actions where a member of the litigation team-generally an investigator rather than the attorney-took pictures or made a contemporaneous report on material evidence (the scene of an accident, the car involved, etc.) which is no longer available in the same form. Cummings v. Bell Tel. Co., 47 F.R.D. 373 (E.D. Pa. 1968); Parrett v. Ford Motor Co., 47 F.R.D. 22 (W.D. Mo. 1968); Maginnis v. Westinghouse Elec. Corp., 207 F. Supp. 739 (E.D. La. 1962); Marks v. Gas Serv. Co., 168 F. Supp. 487 (W.D. Mo. 1958); Julius Hyman \& Co. v. American Motorists Ins. Co., 17 F.R.D. 22 (W.D. Mo. 1958).

161. 422 U.S. at 228.

162. Id. at $239-40$.

163. $5 \mathrm{~J}$. WigmoRE, supra note $1, \S 1368$. 
the other side for impeachment and perhaps substantive purposes. ${ }^{164}$

The issue raised by the hypothetical we are considering differs from the question dealt with in Nobles in several important respects. Most obviously, the materials sought by the prosecution in that case were produced by an investigator working for the defendant's counsel, rather than by counsel himself. As Justice White noted in his concurring opinion in Nobles, the latter case provokes a consideration of "whether the policies against putting in issue the credibility of the lawyer who will sum up to the jury outweigh the jury's interest in obtaining all relevant information."165 But as was developed above, there are substantial reasons for striking that balance in favor of the jury's interest once the attorney has already entered the lists as an affiant.

An even more significant point is that Nobles contains no-indication that the investigator's notes would have revealed in any way what we have called hard-core work product - the mental impressions, conclusions, opinions, or legal theories of counsel. The only reference which the Court made to materials of that kind was a terse indication that when counsel uses his own materials to prepare the case and to examine witnesses, "there normally is no waiver."166 But the advocate's use of materials in the presentation of a case from the outside, as it were, is clearly different from the hypothetical we are considering, where the attorney-affiant steps in as participant. However much his notes may discredit his own witnesses in the former case, it is only in the latter situation that they take on the unique characteristic which made Nobles's investigator's notes discoverable: Only then can they be used to discredit a witness-the lawyer-out of his own mouth.

Suppose, by way of illustration, that counsel's affidavit in support of a motion for a preliminary injunction contains an allegation on information and belief-derived from his interview with a witness unavailable at the moment-that irreparable harm is likely to occur if the relief is not granted. The argument being made here is that the opposing party should be entitled to assess the significance not only of the statements made by the witness which have found their way onto counsel's legal pad (which are not hard-core work product), but also of counsel's reaction to those statements, including interlineations and marginal comments regarding the desirability of the

164. See 422 U.S. at 245-51 (White, J., concurring); Hickman v. Taylor, 329 U.S. 495, 511 (1947).

165. 422 U.S. at 253.

166. Id. at 239 n.14. See also id. at 252-54 (White, J., concurring). 
speaker as a witness, points to emphasize or down-play at trial, and suggestions concerning the weight to be given a particular theory at trial. The reason is that the issue posed by the affidavit is whether the attorney has drawn proper conclusions and given a believable prediction (about irreparable injury) based on the first-hand account of which he was the only auditor. Put another way, we want to know whether the sources of the attorney's information and the grounds for his belief were credible and substantial, and because the attorney was the only person present at the disclosure of the information, his reaction to it is the most important bit of evidence for making that determination. ${ }^{167}$

\section{Attorney Affidavits and Work Product: A Scheme FOR DETERMINING WAIVER}

Part III addressed the justifications for work product protection in the context of an attorney affidavit filed in support of a motion for interlocutory injunctive relief. While the example of the preliminary injunction raises most of the relevant issues, the particular character of an injunction motion disguises a number of variables unique to

167. Considerations similar to those advanced in this section could well lead to waiver of any work product protection for materials used to refresh the recollection of a witness. Federal Rule of Evidence 612 provides that "an adverse party is entitled to have" a writing used to refresh the memory of a witness while testifying, and that the court in its discretion may order production of writings used to refresh the witness's recollection before testifying. Rule 612 is to be interpreted in light of Rule 501, which acknowledges the existence of privileges governed by the Constitution, acts of Congress, and rules prescribed by the Supreme Court, as well as those rooted in the principles of the common law. FED. R. EvID. 501; $3 \mathrm{~J}$. WEINSTEIN \& M. BERGER, supra note 50, at I 612[04]. The issue would be whether the protection provided by Federal Rule of Civil Procedure 26(b)(3) and by what can only be called its common law analogue for nondocumentary materials, see Hickman v. Taylor, 329 U.S. at 512 ("the general policy against invading the privacy of an attorney's course of preparation is so well recognized and so essential to an orderly working of our system of legal procedure that a burden rests on the one who would invade that privacy to establish adequate reasons to justify production through a subpoena or court order."); $i d$. at 514 ("When Rule 26 and the other discovery rules were adopted, this Court and the members of the bar in general certainly did not believe or contemplate that all the files and mental processes of lawyers were thereby opened to the free scrutiny of their adversaries."), overrides the policy of FED. R. EviD. 612. At least one commentator has suggested that the rule should eliminate any available work product protection. Comment, Witnesses Under Article VI of the Proposed Federal Rules of Evidence, 15 WAYNE L. REV. 1236, 1274 (1969). The requirement of disclosure of refreshment materials is based on the danger that they will be palmed off to the jury as the witness's present recital of the event in question, when in fact he has no recollection at all, and the opportunity that they offer to demonstrate that the witness's recollection, already once drawn into question, is faulty. See C. MCCormick, HANDBOOK OF THE LAW of Evidence $\S 9$, at 17 (2d ed. 1972); 3 J. WIGMORE, supra note $1, \S 762$, at 138-39. In both regards the material is essential to effective cross-examination, and hence shares the quality which it was urged in text made the attorney-affiant's work product discoverable. 
other types of attorney affidavits-those employed to verify pleadings, to assist in the discovery process, to seek or oppose complete or partial summary judgment, or to secure or defeat the grant of a new trial. The discovering party's need for the information is a prerequisite to disclosure under Rule 26(b)(3), and by extension, under the more undefined work product doctrine applicable to nondocumentary information. ${ }^{168}$ This need obviously may vary with the type of order which counsel's affidavit helps secure. A second element in the work product analysis which may change as the litigation progresses is the foundation required to support any statement which an attorney may make under oath. Though information and belief may suffice at more preliminary stages, ${ }^{169}$ first-hand knowledge is required for applications for summary judgment and for new trial. ${ }^{170} \mathrm{~A}$ third variable-one whose relevance depends not on the stage at which an affidavit is offered but on the justification advanced for protecting work product-is the extent to which the court has relied on counsel's statement in issuing or refusing a requested order.

Applying these criteria helps determine whether a particular affidavit works a waiver of work product protection. But two questions then remain, which this part also tries to resolve: If disclosure of work product is to be ordered, what should be its scope? And is there a duty imposed on the attorney to release after-acquired work product once the initial disclosure has been ordered?

\section{A. The Type of Relief Secured}

The form of relief an attorney seeks and secures by filing an affidavit is perhaps the crucial factor in applying virtually all the conventional arguments for protecting work product. Verifying a pleading, because it never even temporarily resolves either substantive or procedural disagreements between the parties, should not cause a waiver of normal work product protection. ${ }^{171}$ On the other

168. See note 120 supra and accompanying text.

169. See FED. R. Grv. P. 11.

170. See Fed. R. Crv. P. 56(e).

171. Thus the "proprietary" argument is strongest when the attorney filing the affidavit has secured no relief against the opposing party. Similarly, if we assume that trial preparation will suffer if disclosure is ordered, there is good reason to believe that any lawyer worth his salt will put his client to the trouble of verifying the pleadings rather than risk losing the benefits of his own discovery. But forcing attorney and client to run that inconvenience is precisely what statutes authorizing verification are designed to avoid. Finally, if attorneyclient relations really do suffer when the attorney is forced to take the stand, see notes 145-46 supra and accompanying text, it is likely to be of small moment to the client that the attorney verified a pleading and risked being put on the stand just to save the client a trip into the next county to sign a complaint. 
hand, in the example of the motion for a preliminary injunction we assumed that because the defendant was subjected to the hardship of a temporary injunction, he should be permitted to penetrate the work product materials relevant to the plaintiff attorney's affidavit. We still must consider whether work product is waived by the filing of an affidavit in the other typical situations-discovery motions, summary judgment, and motions for a new trial.

The extraordinary range of relief available at the discovery stage $^{172}$ makes it difficult to generalize about affidavits at this point in the litigation. Since the varieties of relief dispositive of the litigation will be considered below, it may be most instructive to deal simply with a case where counsel for the plaintiff has filed his own affidavit in support of a motion to expedite discovery on the basis of his view of the merits.

If the proprietary argument for work product protection has any validity, it is more persuasive here than it would be in the case of a motion for a preliminary injunction. An order granting expedited discovery does not directly affect the parties' liabilities outside the litigation process. Moreover, the order would most likely be evenhanded, directing that the parties proceed with discovery at the same pace.

The relevance of the trial preparation argument to an order to expedite discovery is a closer question. A party's need for expedited discovery may be great enough to overcome any fear that it will waive work product protection if its counsel files an affidavit. On the other hand, one can easily imagine cases where the urgency of discovery might not be quite so pressing. In such a case, the disclosure of work product might well work as a disincentive to preparation. Thus if we are to presume that this argument has real empirical merit (an assumption which Part III suggested might be unwarranted), the court should assess in each case the chance of discouraging future preparation, given the need of the moving party for the relief sought.

As for the danger that the responding party will call the moving counsel to the stand, by the time of a preliminary discovery motion counsel has usually gathered too little information to become a useful

172. Where a party fails to comply with discovery the Federal Rules provide sanctions ranging from a simple stay of further proceedings to dismissal of the action or default judgment. See FED. R. Crv. P. 37(b). Judicial orders are available for an almost endless variety of other purposes. See, e.g., note 11 supra and accompanying text. Counsel could presumably file an affidavit addressing the merits of the litigation in connection with any of these forms of relief. 
trial witness for the opposition, even if he were required to turn over work product materials. This fact, of course, speaks in favor of disclosure and against the danger of the responding party requiring counsel to testify. Further, as we saw earlier, before filing an affidavit counsel will normally have resolved any potential conflicts between his statements and the likely testimony of his witnesses. ${ }^{173} \mathrm{But}$ if there is any persuasive force to the claim that attorney-client relations might be strained if counsel is forced to take the stand, it may well be that the client is no more kindly disposed toward that predicament simply because his lawyer earlier succeeded in expediting discovery..$^{174}$

Finally, whatever arguments favor discovery of general work product, hard-core work product merits more protection after affidavits filed at the discovery stage. In contrast to preliminary injunctive relief, expedited discovery creates considerably less need for crosschecking the affiant-attorney's private evaluation of the merits. The hardship to the party losing the motion is greatly diminished in the latter case, and probably insufficient to warrant exposing the opponent's trial strategy for which Rule 26(b)(3) shows such solicitous regard.

A grant of summary judgment obviously entails even more drastic consequences for the responding party than an interlocutory injunction. Thus, to the extent that affidavits of counsel help secure summary judgment, the court should incline all the more toward finding waiver of work product protection in this situation. If summary judgment warrants analysis different from that we have given injunctions, we must look to the differing foundations required of attorney affidavits in these two situations. ${ }^{175}$

The application of the work product arguments to motions for a new trial is more complicated. As we have seen, the attorney filing such a motion will typically seek to support it with extra-record facts, such as newly discovered evidence, facts showing jury misconduct, or misconduct of the opposing party or counsel outside the courtroom. As in the case of summary judgment, counsel's affidavit could play no part in determining the merits of the motion unless his statement would be admissible at trial. ${ }^{176}$

173. See text accompanying note 149 supra.

174. The client's reaction naturally will depend on a number of other factors, including his sophistication and the actual urgency of early discovery.

175. See text accompanying notes 181-82 infra.

176. The issues on a motion for new trial are thus different from those that arise when work product discovery is sought in subsequent litigation. Cf. Duplan Corp. v. Moulinage et Retorderie de Chavonoz, 487 F.2d 480, 485 (4th Cir. 1973) (production of work product 
Suppose that shortly after losing a verdict in an aircraft collision case plaintiff's counsel obtains from a private detective a flight log suggesting that defendant's craft departed from its flight plan shortly before the collision. On a motion for a new trial counsel files an affidavit identifying the document and stating that counsel overheard defendant, while leaving the courtroom, say to his lawyer, "It's a good thing they didn't know the altimeter was broken." In connection with the motion defendant seeks disclosure of all documents in plaintiff's counsel's possession relevant to the new evidence and the use counsel would make of it at a new trial. ${ }^{177}$ The issue is whether the defendant is entitled to obtain, for example, a copy of a memorandum in counsel's file stating that "the most serious obstacle to our motion, if it should come out, is the fact that the air traffic controller told me yesterday that defendant was not out of his flight plan. He may only have thought so because his altimeter was broken, and have recorded that inaccurate fact in the log."

The proprietary argument for work product protection is as weak here as it is at the preliminary injunction stage. Whatever proprietary claim plaintiff's counsel might assert to the facts he learned from the traffic controller, that right surely does not entitle him to overturn the defendant's verdict on the basis of his own affidavit, when that affidavit may be inconsistent with the supposedly proprietary facts.

The trial preparation argument for work product preparation is no more persuasive. Having already lost the case, and having at the outset only the slenderest chance of succeeding on a motion for a new

materials prepared in prior unrelated case ordered only if "substantial need and undue hardship" shown); Honeywell, Inc. v. Piper Aircraft Corp., 50 F.R.D. 117 (M.D. Pa. 1970) (discovery of documents relating to prior cases allowed where prior cases no longer pending, defendants not parties to those actions, and no indication documents prepared "with an eye toward [this] litigation"); Hanover Shoe, Inc. v. United Shoe Mach. Corp., 207 F. Supp. 407 (M.D. Pa. 1962) (production ordered of counsel's memorandum prepared at meeting regarding prior suit where contents could not be learned from anyone else and defendant sought to confront plaintiff with contents at trial without allowing plaintiff chance to consider legal ramifications of statement made at meeting); Note, Discovery of an Altomey's Work Product in Subsequent Litigation, 1974 DUKE L.J. 799; Discovery Developments, supra note 117, at 1044.

177. Cf. Edgar v. Finley, 312 F.2d 533 (8th Gir. 1963) (court improperly sustained plaintiff's objections to interrogatories on basis of privilege even though information requested was furnished to defendant's attorney in confidence); N.Y. COUNTY LAWYERS' AsSOciation, Committee on Professional Ethics, Opinions, No. 64 (1915), reprinted in Opinions of the Committees on Professional Ethics of the Association of the BAR OF THE CITY OF NEW YORK AND THE NEW YORK COUNTY LAWYERS' AsSOciation 547 (1956) (plaintiff's attorney may testify about matters voluntarily admitted during meeting with defendants, but should withdraw as trial counsel if he does so). 
trial, ${ }^{178}$ plaintiff's counsel will certainly spare no effort to uncover favorable new evidence. While the improbability of plaintiff succeeding on a new trial motion, coupled with the possibility of getting a look at plaintiff's counsel's file, may induce the victorious defendant to be less diligent than usual in trial preparation, that danger seems negligible compared to that of an unfair verdict based on possibly inaccurate information. Moreover, by filing an affidavit on first-hand knowledge, counsel has chosen to become a full-fledged witness in any evidentiary hearing that might be held. Any tension between his roles as litigator and witness is entirely of his own making. Even with regard to hard-core work product counsel would probably be in no better position regarding his notes than was the investigator in Nobles ${ }^{179}$ regarding his written report. Since counsel has made a "testimonial use" of his work product, it is subject to the normal rules of evidence. ${ }^{180}$

\section{B. The Foundation Required to Support Counsel's Affidavit}

We have seen that affidavits filed in connection with verification of pleadings, discovery, or motions for interlocutory injunctive relief may be made on information and belief rather than on first-hand knowledge, ${ }^{181}$ while those considered on summary judgment or new trial motions must contain such matter as would be admissible in evidence. ${ }^{182}$ This difference in the foundation required to support counsel's affidavit will affect the protection which work product deserves once the affidavit is filed. As the discussion of United States $v$. Nobles in Part III indicated, once an attorney has filed an affidavit, even hard-core work product may lose protection if the opposing party needs it for cross-examination at trial. What is more, protection may be lost whether counsel's affidavit is filed on information and belief or on personal knowledge. But there is one critical difference between the two cases. The justification for discovery where information and belief provided the foundation was the need to assess the credibility and persuasiveness of a witness statement which counsel

178. See, e.g., Trans Miss. Corp. v. United States, 494 F.2d 770 (5th Cir. 1974) (evidence which is merely cumulative or impeaching does not generally warrant new trial); United States Fidelity \& Guar. Co. v. Lawrenson, 334 F.2d 464, 466 (4th Gir.), cert. denied, 379 U.S. 869 (1964) (evidence which has previously been offered or is merely cumulative or impeaching is not new evidence); F. James \& G. HAzard, Grvil Procedure 691 (2d. ed. 1977); 11 C. WRIGHT \& A. MilleR, supra note 9 , at $§ 2859$.

179. 422 U.S. at 239 n.14.

180. See notes $160-64$ supra and accompanying text.

181. See notes 169-70 supra and accompanying text.

182. FED. R. GIV. P. 56(e). 
was the only person to hear. It thus became important to probe the lawyer's own mental impressions insofar as they related to those issues.

But once the witness himself becomes available, the attorney's mental impressions-indeed his affidavit itself-become superfluous. If the court which issued the preliminary injunction concluded that irreparable injury was likely on the basis of what the witness told counsel, both judge and opposing party can now reopen the matter with a first-hand-rather than hearsay-account.

On the other hand, in those cases where counsel has filed an affidavit based on personal knowledge, there will never come a point when what he has said becomes superfluous. When the court grants injunctive relief, denies partial summary judgment, or denies a new trial on the basis of counsel's first-hand statement, it will always be true that the most effective means of overturning the court's order will be to disprove counsel's claim out of his own mouth.

\section{The Court's Reliance on the Affidavit}

The third variable affecting work product protection is the extent to which the court has actually relied on counsel's affidavit in deciding to grant relief, regardless of the particular type of relief secured. The reliance factor does not bear equally on all the traditional arguments for work product protection. The danger of discouraging trial preparation, for example, varies not so much with the use the court ultimately makes of the affidavit as with the lawyer's sense of the urgency of gathering information. But the extent of the court's reliance on the affidavit certainly helps determine the danger of the affiant-attorney being called to the witness stand, since the greater the reliance, the more likely the opposing party will see it in its interest to examine the affiant. Unlike the proprietary and hard-core arguments, the claim against discovery based on the attorney-as-witness argument thus varies directly-rather than inversely-with the court's reliance. Since the intuitive sense that it is unfair to obtain another party's work product depends heavily on the question whether the owner of the work product has put it to great use in litigation, a showing of stronger reliance diminishes the force of the proprietary argument. Finally, to the extent that the court has relied on the affiant's personal evaluation of facts, the affiant may have waived even hard-core work product protection, since the need for cross-checking the accuracy of counsel's claims grows with the size of the part they play in the grant or denial of serious affirmative relief. 
The reliance element obviously differs from the other variables in that the judge will in a sense have to examine his own thinking to measure it in a particular case. But it is well to reiterate that where the court does rely on counsel's affidavit, it is not only those matters which support the statements made which may be discovered. Even more crucial is the right to inspect what counsel omitted, so long as it relates to the subject matter of the affidavit.

\section{The Scope of Disclosure}

As noted above, work product discovery hinges on showings of "substantial need" and inability to obtain the "substantial equivalent" of the information sought. ${ }^{183}$ Once the criteria discussed above-the type of relief secured, the foundation required for the affidavit, and the court's reliance on the affidavit-determine whether work product protection is waived, these requirements also serve as benchmarks for determining the scope of work product discovery. The "need" and "equivalence" test contrasts with the normal test for discovery set forth in Rule 26(b)(1): "relevan[ce] to the subject matter." 184 The practical consequence of this difference should be to allow discovery of any information bearing on the accuracy and completeness of statements made in counsel's affidavit and relied upon by a court in granting relief. In other words, the scope of discovery in such cases should be as wide as the scope of cross-examination. ${ }^{185}$ This is the only certain way to avoid the unilateral "testimonial use of [work product] materials" condemned in Nobles. ${ }^{186}$ Under this rule, hard-core work product requires no special treatment. Once the accuracy of the attorney's perception and the truth of his statement, or the source of his information and grounds for his belief, are put in issue-as they must be by an affidavit-no special concern ought to attach to his mental impressions or personal evaluation of the case.

\section{E. Disclosure of After-acquired Work Product}

A final question is whether the affiant-attorney has a continuing responsibility to disclose work product, after the initial required disclosure. The example of the preliminary injunction in Part III suggests the need for such a duty. Suppose that in issuing the injunction the court makes clear its heavy reliance on the hearsay statements set

183. FED. R. Crv. P. 26(b)(3); see notes 118-20 supra and accompanying text.

184. FED. R. Crv. P. 26(b)(1).

185. See FED. R. Evid. 611(b).

186. 422 U.S. at 239 n.14; see notes 158-64 supra and accompanying text. 
forth in counsel's affidavit. If several weeks later, after interviewing other witnesses, counsel decides that the original statements were inaccurate and therefore does not intend to press their accuracy at trial, the grant of injunctive relief based on the court's reliance on the attorney's affidavit constitutes the enjoined party's "substantial need" for such information.

Although it does not directly address the problem, Rule 26(e) provides a useful definition of the circumstances under which disclosure of after-acquired work product should be made:

A party is under a duty seasonably to amend a prior response if he obtains information upon the basis of which (A) he knows that the response was incorrect when made, or (B) he knows that the response though correct when made is no longer true and the circumstances are such that a failure to amend the response is in substance a knowing concealment. ${ }^{187}$

The reason for restricting the duty of supplementation to parties is that nonparty witnesses will seldom be familiar enough with the facts and issues of the litigation to know whether after-acquired information is material to the litigation. ${ }^{188}$ Moreover, the Federal Rules may seek to avoid burdening those whose only involvement in the case stems from their fulfillment of a public duty to provide evidence in their possession.

Counsel fits neither of those descriptions. Rule 26(e) does not explicitly apply to counsel because the work product and attorneyclient protections make discovery from counsel an extraordinary event. ${ }^{189}$ But once work product protection is lost there is little reason to restrict disclosure to materials and information which are in counsel's possession at the time the affidavit is filed.

\section{Conclusion}

Although trial attorneys commonly file affidavits in connection with litigation in which they are involved, little thought has been given to the circumstances which make such active participation desirable or proper, and to the consequences which it may have for the

187. FED. R. Crv. P. 26(e)(2). The rule speaks only of parties. Discovery of work product, on the other hand, would be made either by taking the deposition of the attorney, or serving him with a subpoena duces tecum pursuant to FED. R. CrV. P. 45.

188. For an analysis of the circumstances in which courts compel disclosure of afteracquired work product, see 8 C. WRIGHT \& A. MILLER, supra note 9, § 2049, at 324.

189. Of equal importance, perhaps, is the simple fact that even contentions and conclusions of counsel, in addition to facts and theories, may be secured by serving the party with interrogatories, FED. R. Crv. P. 33(b), or requests for admissions, FED. R. Grv. P. 36(a). 
discovery process. This article has attempted to suggest that the ethical concerns which attend lawyers' testimony at trial apply with considerably less force to statements under oath made during more preliminary stages of a lawsuit. Whether the arguments generally advanced against taking the stand apply at all is a matter which depends on several factors: the extent to which the attorney's affidavit draws him into disputed issues close to the merits, the type of relief sought by a motion supported by counsel's affidavit, the foundation required to support counsel's statement, which may range from information and belief to personal knowledge, and the relative need for prompt action which moves the attorney to dispense with alternate sources of proof.

The latter half of this essay discussed the question whether counsel, by making his own statement under oath regarding the merits of the controversy, has waived the protection generally given to work product. There again it is argued that the underpinnings of traditional doctrine do not support a rule of nondisclosure with nearly the same strength once an affidavit has been filed. Whether the protection is waived again depends on several factors: the type of relief secured, the foundation required to support counsel's affidavit, and the extent to which the court relied on the attorney's statement in issuing or refusing a requested order. Where disclosure is appropriate, its scope should be as wide as that usually permitted for cross-examination, and there should be a duty imposed on counsel to release afteracquired work product falling within that range. 